\title{
Foraminifera of the Toarcian-Aalenian boundary from the Lusitanian Basin (Portugal): a paleoecological analysis
}

\author{
V. Figueiredo ${ }^{1}$, M.L. Canales²*, M.H. Henriques ${ }^{3}$ \\ ${ }^{1}$ Laboratório Nacional de Energia e Geologia, Estrada da Portela, Bairro do Zambujal - Alfragide, 2610-999 Amadora. Centro \\ Geociências da Universidade de Coimbra, Largo Marquês de Pombal, 3049 Coimbra, Portugal. \\ ${ }^{2}$ Departamento de Paleontología, Facultad de Ciencias Geológicas, Universidad Complutense de Madrid, c/ José Antonio \\ Novais, 12, 28040 Madrid, Spain. \\ ${ }^{3}$ Departamento de Ciências da Terra, Faculdade de Ciências e Tecnologia, Universidade de Coimbra e Centro de Geociências \\ da Universidade de Coimbra, Largo Marquês de Pombal, 3049 Coimbra, Portugal.
}

e-mail addresses:verfigueiredo@gmail.com (V.F.); mcanales@geo.ucm.es (M.L.C.; *corresponding author); hhenriq@dct.uc.pt (M.H.H.)

Received: 9 January 2014 / Accepted: 22 May 2014 / Available online: 30 October 2014

\begin{abstract}
A detailed study carried out on 37 well preserved benthic foraminiferal assemblages sampled throughout the upper Toarcian-middle Aalenian in two well calibrated sections representing different facies within the Lusitanian Basin (Portugal) - the Maria Pares and the Zambujal de Alcaria sections - allows interpreting the past environmental conditions. Several mathematical indexes related to diversity, which enable establishing the particular conditions to which the assemblages were submitted, were applied. All the studied assemblages are characteristic of the Jurassic carbonate platforms of the Boreal Realm, in which the genus Lenticulina usually dominates. The suborder Lagenina is the most abundant, but taking the second more abundant suborder into account, the comparison between coeval sections in the Lusitanian Basin allows the recognition of a regional gradient ranging from the distal part of the platform (Murtinheira) towards the transitional and proximal parts of the shelf (sections of Maria Pares and Zambujal de Alcaria respectively). The relative abundance values, as well as the obtained data from the diversity indexes indicate that the studied assemblages are relatively abundant and diverse, reflecting general appropriate paleoenvironmental conditions for their development. The detailed analysis of the data allows the identification in both sections of three different episodes, traducing particular environmental conditions: unstable (Mactra Subzone-lower part of the Opalinum Subzone), favorable and stable (lower part of the Opalinum Subzone-upper part of the Comptum Subzone), and unfavorable (upper part of the Comptum Subzone-lower Bradfordensis Subzone). These data are consistent with previous results obtained in the sections of Murtinheira and São Gião, located in the Northern Lusitanian Basin and corresponding to the distal and transitional parts of the platform respectively, and they aimed at contributing to a better understanding of the paleoecological conditions prevailing within the Lusitanian Basin during the Early-Middle Jurassic times.
\end{abstract}

Keywords: Benthic foraminifera, Lower-Middle Jurassic boundary, Portugal, paleoecology, diversity index, Paleoenvironmental gradient

Resumen

Se ha realizado el estudio detallado de 37 asociaciones de foraminíferos bentónicos bien preservados, registradas en materiales del intervalo estratigráfico Toarciense superior-Aaleniense medio en dos secciones bien calibradas que representan diferentes facies dentro de la Cuenca Lusitánica (Portugal) - Maria Pares y Zambujal de Alcaria - permitiendo realizar interpretaciones de las condiciones paleoambientales. Para ello, se han aplicado varios índices matemáticos relacionados con la diversidad, que permiten establecer las condiciones ambientales concretas en las que se desarrollaron dichas asociaciones. Todas las asociaciones estudiadas son características de las plataformas carbonatadas jurásicas del Dominio Boreal, en las que predominan los representantes del género Lenticulina. El suborden Lagenina es el más abundante, pero teniendo en cuenta el segundo suborden más importante, la comparación entre diferentes secciones contemporáneas en la Cuenca Lusitánica permite reconocer un gradiente regional, desde la zona distal (Murtinheira) hasta las zonas de transición y proximal de la plataforma (Maria Pares y Zambujal de Alcaria, respectivamente). Los valores de abundancia relativa, así como los datos obtenidos a partir de los índices de diversidad, indican que las asociaciones estudiadas son relativamente abundantes y diversas, reflejando condiciones ambientales en general adecuadas a su desarrollo. El análisis detallado de los datos permite reconocer en ambos perfiles tres episodios distintos, en los que se dieron condiciones ambientales diferentes: inestables (Subzona Mactra-parte superior de la Subzona Aalensis), favorables y estables (parte superior de la Subzona Aalensis-parte superior de la Subzona Comptum) y desfavorables (parte superior de la 
Subzona Comptum-parte inferior de la Subzona Bradfordensis). Estos datos coinciden con resultados previamente obtenidos en las secciones de Murtinheira y São Gião, que se localizan en el norte de la Cuenca Lusitánica y corresponden a la zona distal y de transición de la plataforma respectivamente, lo que permite una mejor comprensión de las condiciones paleoecológicas que se dieron en la Cuenca Lusitánica durante el Jurásico Inferior-Medio.

Palabras clave: foraminíferos bentónicos, límite Jurásico Inferior-Medio, Portugal, paleoecología, índice de diversidad, gradiente paleoambiental

\section{Introduction}

Benthic foraminiferal assemblages have been currently used as proxies for determining paleoecological features, which may have controlled their development due to the close relation between them. According to Hammer and Harper (2006), paleoecological features are best described, analyzed and compared using numerical data. In this sense, the high number of specimens that usually can be found in the foraminiferal assemblages allows the use of various mathematical indexes related to diversity, abundance and dominance, hence supporting interpretations about the particular conditions to which the assemblages were submitted.

Two reference sections of the Lower-Middle Jurassic transition of the Lusitanian Basin have been analyzed in order to interpret past environments at regional level based on the recorded foraminiferal assemblages: the Maria Pares section, located at the northern sector of the basin, and the Zambujal de Alcaria section, located at the central part of the basin. For such purpose previous detailed biostratigraphic background supported by the recorded ammonites (Henriques, 1992, 1995), as well as sedimentological data allowing the interpretation of the location of the studied sections within the basin (Azerêdo et al., 2003; Azerêdo, 2007) were taken into account.

Prior studies based on the foraminifera from the EarlyMiddle Jurassic in the Lusitanian Basin have been carried out mainly in the last decades (Exton, 1979; Exton and Gradstein, 1984; Ruget, 1985; Stam, 1985; Azerêdo, 1993, 1995, 1999; Henriques et al., 1995; Carapito and Henriques, 1999; Canales et al., 2010; Canales and Henriques, 2007, 2008, 2013; Magno et al., 2008; Magno, 2010; Henriques and Canales, 2013).

Sectorial data regarding the foraminiferal assemblages recorded in the two sections analyzed which represent different facies within the Lusitanian Basin, can be found in Figueiredo (2009), Figueiredo et al. (2010a, 2010b), Guterres (2010), Canales et al. $(2010,2014)$ and Figueiredo and Guterres (2012). However, no integration of the paleoecological data resulting from the interpretation of the benthic foraminiferal assemblages recorded in each section has been so far carried out in order to determine variations in the environmental conditions across the Lower-Middle Jurassic transition within the different sections and sectors of the basin. Nor were analyzed taking into account previous results obtained in other coeval sections of the Lusitanian Basin - the Murtinheira section, corresponding to the distal part of the platform, and the
São Gião section, corresponding to the transitional part of the platform, both located in the Northern sector of the basin - thus enabling the interpretation of the detailed paleoecological conditions prevailing within different sectors and areas of the Lusitanian Basin during the Early-Middle Jurassic times.

\section{Geographical location and geological setting}

The Lusitanian Basin is located on the western edge of the Iberian Peninsula (Fig. 1A) and corresponds to a sedimentary basin whose genesis and evolution were determined by the opening of the Atlantic Ocean. It displays a NE-SW direction, extending along a length of approximately $300 \mathrm{~km}$ by $150 \mathrm{~km}$ width, including the immersed area. The sedimentary record, covering from Upper Triassic to Upper Cretaceous has an estimated maximum thickness of approximately 5 km (Ribeiro et al., 1979; Wilson, 1988; Wilson et al., 1989). The Jurassic record is particularly well exposed in several outcrops where it is mainly represented by marine carbonate rocks of Early and Middle Jurassic age, and siliciclastic sediments of Late Jurassic age.

The Maria Pares section is located in the northern sector of the Lusitanian Basin, in the region of Rabaçal, approximately $8 \mathrm{~km}$ SE of Condeixa-a-Nova (Fig. 1B).

The studied stratigraphic interval, ranging from upper Toarcian to middle Aalenian, corresponds to the Póvoa da Lomba Formation (sensu Azerêdo et al., 2003; Duarte, 2007; Barbosa et al., 2008) and to the underlying Degracias Formation, interpreted as typical facies corresponding to the middle part of the platform (Azerêdo et al., 2003; Azerêdo, 2007).

The first group of facies is represented in this section by a $15.8 \mathrm{~m}$ thick succession of grey marls and marly limestones, displaying a progressive increase in the calcareous component towards the top, and including an abundant and diversified ammonite record (Henriques, 1992, 1995; Henriques and Canales, 2013).

The second group of facies corresponds to a $4.5 \mathrm{~m}$ thick interval of compact bluish-gray micritic limestones (Calcários azuis do Poço Central in Henriques, 1992). The boundary between them corresponds to a regional stratigraphic gap represented by the absence of record of the Haugi and Murchisonae subzones at the lower part of the middle Aalenian (Henriques, 1992, 1998; Azerêdo et al., 2003), which coincides with the base of the cycle ZA 1 of Haq et al. (1988).

The Zambujal de Alcaria section is located in the central sector of the Lusitanian Basin, in the eastern region of the Maciço Calcário Estremenho, approximately $5 \mathrm{~km} \mathrm{SSW} \mathrm{of}$ 


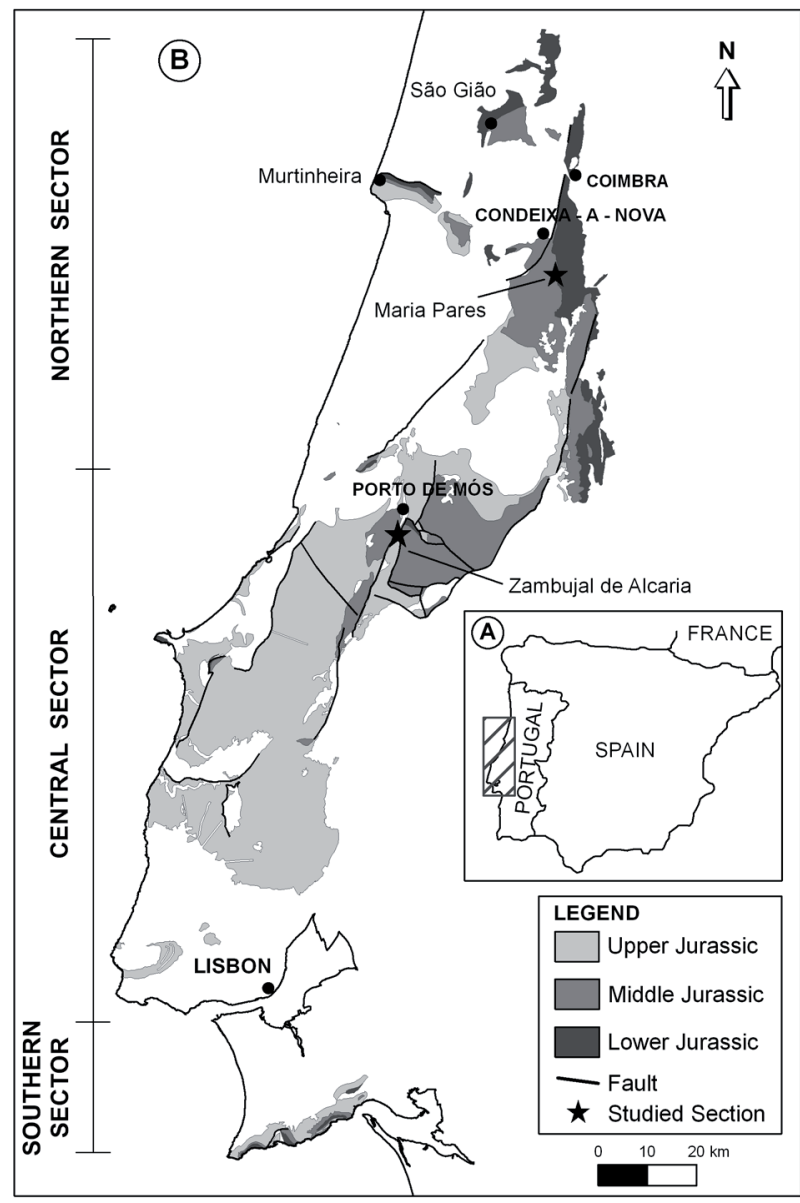

Fig. 1.- (A) Geographical location of the Lusitanian Basin (Portugal). (B) Location of the sections of Maria Pares (northern Lusitanian Basin) and Zambujal de Alcaria (central Lusitanian Basin) (Modified after the Geological Map of Portugal, scale 1:1,000,000).

Porto de Mós (Fig. 1B). The studied stratigraphic interval, from upper Toarcian to middle Aalenian, corresponds to the Fórnea Formation and to the underlying Barranco do Zambujal Formation, interpreted as typical depositional facies of proximal internal marine ramp (Azerêdo et al., 2003; Azerêdo, 2007). The Fórnea Formation is represented by a 22 $\mathrm{m}$ thick succession of grey marly limestones and marls, containing an abundant and diversified fossil content of nektonic groups (ammonites, belemnites). The Barranco do Zambujal Formation is represented by a $17.5 \mathrm{~m}$ thick of a grey rhythmic alternation of marls, marly limestone and clay limestone, showing increasing bed thickness and carbonate content towards the top (Azerêdo et al., 2003; Azerêdo, 2007), corresponding to a shallowing upwards sequence.

\section{Materials and methods}

The paleoecological analysis performed on the recorded assemblages of foraminifera, was based on the study of a total of 37 samples collected from the upper Toarcian to the middle Aalenian in both sections. The main criteria adopted for sampling was the stratigraphic units based on ammonites
(Henriques, 1992, 1998, 2000), as well as the lithological features (marls or marly limestones) and the exposure conditions of the outcrops. Differences in sampling (17 samples from the Maria Pares section and 20 from the Zambujal de Alcaria section) result from the reduced thickness of the Opalinum Subzone in the first section (Figs. 2 and 3). The samples were identified as MP for the Maria Pares section, ZB for the Toarcian-Aalenian (including the Opalinum Subzone) of the Zambujal de Alcaria section, and ZA for the lowermiddle Aalenian (Comptum and Bradfordensis subzones) of the same section, followed by the number of the level in the respective stratigraphic section.

Approximately $300 \mathrm{~g}$ of each sediment sample were treated in laboratory following a chemical treatment, using 8 tablets $\mathrm{NaOH}, 400 \mathrm{ml} \mathrm{H}_{2} \mathrm{O}_{2}$ and $400 \mathrm{ml} \mathrm{H}_{2} \mathrm{O}$. After three days, they were washed in a column of mesh sieves $(1 \mathrm{~mm}$, $0.500 \mathrm{~mm}, 0.250 \mathrm{~mm}, 0.125 \mathrm{~mm}$, and $0.060 \mathrm{~mm}$ ). Picking of the residue of the three intermediate fractions and the subsequent study of the obtained foraminifera was carried out using binocular magnifying glass (BMS-141 and Wild M5A). Suprageneric and generic identifications followed the classification of Loeblich and Tappan (1987), and the Ellis and Messina (1940-1990) Catalogue of Foraminifera was systematically consulted for specific determinations. The figured specimens were photographed with a JEOL-JSM 6400 electron microscope, located in the Centro Nacional de Microscopía Electrónica at the Universidad Complutense de Madrid (Spain). All sample residues and specimens are stored at the Laboratório de Geologia Sedimentar e Registo Fóssil, located at the Departamento de Ciências da Terra of the Faculdade de Ciências e Tecnologia of the Universidade de Coimbra (Portugal).

For the paleoecological study of the assemblages, relative abundances at different taxonomical levels, expressed as a percentage in relation to the total number of specimens obtained in each assemblage, were calculated. In addition, some diversity indexes were also calculated, namely species richness indexes (the Fisher' $\alpha$ diversity index and the Margalef's richness index) and indexes based on the proportional abundance of species (Simpson index, Berger-Parker index, Shannon-Wiener index and Pielou's equitability index) (Canales, 2001) using PAST (Hammer et al., 2001; Hammer and Harper, 2006).

To evaluate diversity, one of the most widely used indexes is the Fisher's $\alpha$ diversity index, whose mathematical expression is $S=\alpha(x) \ln (1+n / \alpha)$, where $S$ : number of species and $n$ : sample size (Hammer and Harper, 2006). The Margalef's richness index relates the total number of species with the number of specimens in each sample. Its mathematical expression is $\mathrm{S}=\mathrm{S}-1 / \mathrm{lnN}$, where $\mathrm{S}$ : number of species and $\mathrm{N}$ : number of specimens (Magurran, 1988).

The Simpson index refers to the dominance of a species over the total number of species. It indicates the probability that two randomly picked individuals belong to the same species. Its mathematical expression is $\lambda=\Sigma \mathrm{p}_{\mathrm{i}}^{2}$, where $\mathrm{p}_{\mathrm{i}}=\mathrm{n}_{\mathrm{i}} / \mathrm{n}$, 


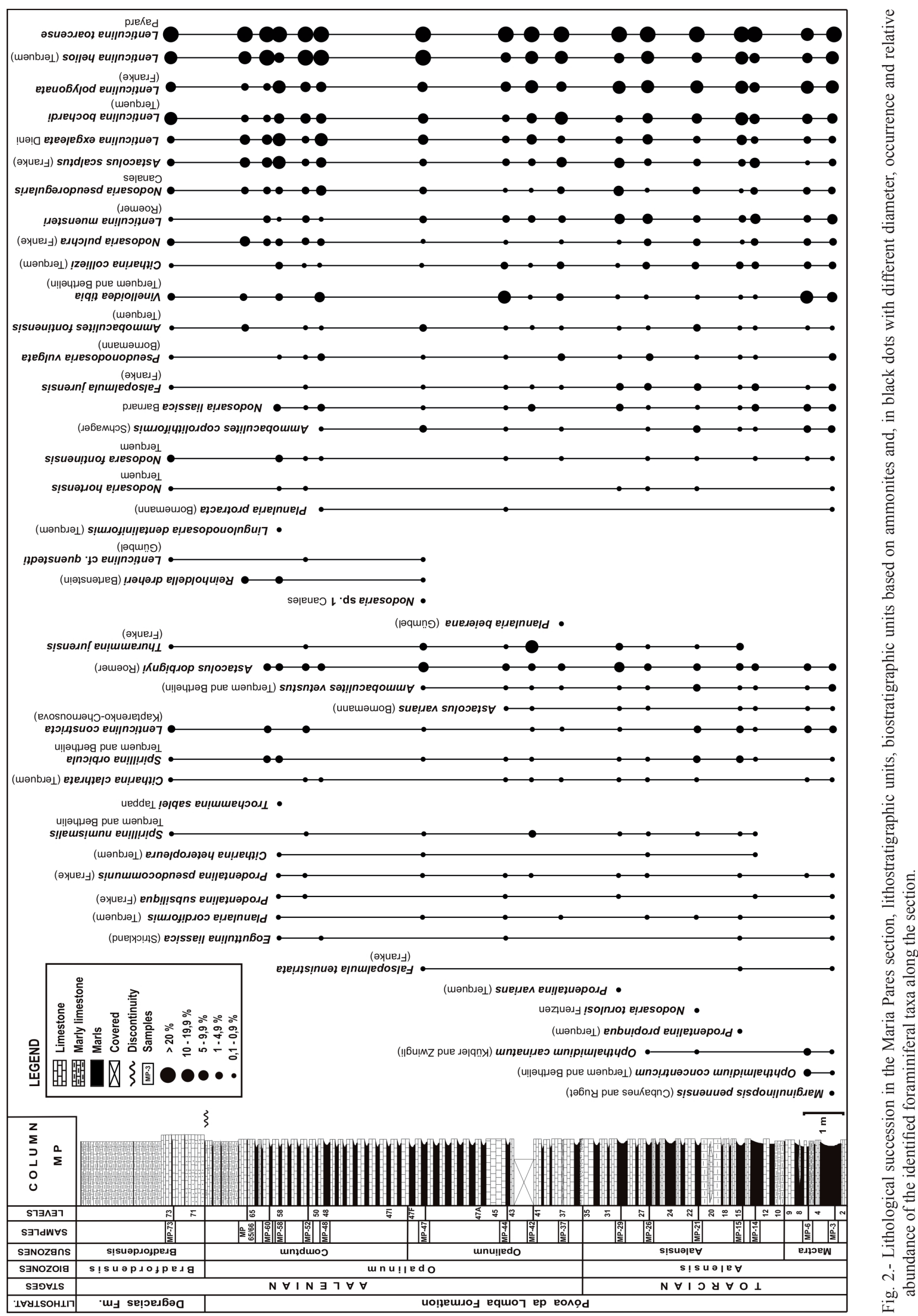




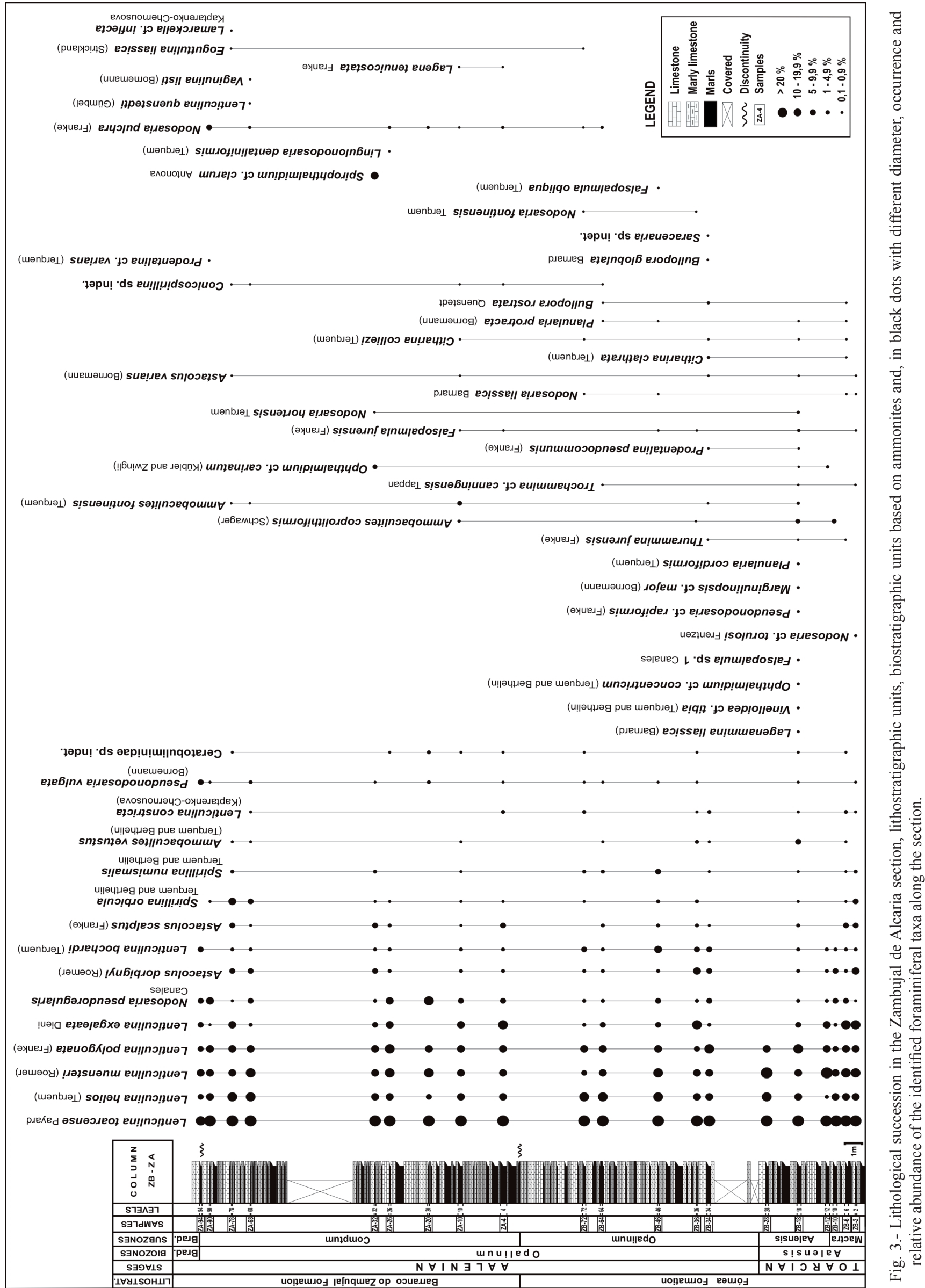


being $n_{i}$ : number of specimens of each species, and $n$ : total number of specimens (Hammer and Harper, 2006). The Berger-Parker index quantifies the dominance by relating the number of specimens of the more abundant taxa with the sample size (Hammer and Harper, 2006). The Shannon-Wiener index expresses the difficulty of predicting to which species will belong the next specimen obtained in an assemblage and its mathematical expression is $H^{\prime}=-\Sigma p_{i}(x) \ln _{i}$, where $p_{i}=n_{i} / n$, being $n_{i}$ : number of specimens of each species, and $n$ : total number of specimens (Hammer and Harper, 2006). Finally, the Pielou's equitability index refers to the distribution of specimens among the species of an assemblage and its mathematical expression is $\mathrm{J}=\mathrm{H}^{\prime} / \mathrm{lnS}$, where $\mathrm{H}^{\prime}$ : Shannon-Wiener index and $S$ : total number of species (Hammer and Harper, 2006). The variation of value of the calculated indexes along the studied stratigraphic interval were further analyzed and interpreted as the basic data for the performed paleoecological reconstruction.

\section{Results}

A total of 18,811 specimens were obtained, corresponding to 5 suborders - Textulariina, Spirillinina, Miliolina, Lagenina and Robertinina -, 13 families, 26 genera and 66 species (Figs. 2 and 3 , and supplementary data). No evidence of taphonomic processes that could modify the composition of the original assemblage has been recognized. In a few cases, determinations were limited to the generic level, or even to the family level, due to fragmentation, partial or total dissolution of the shells (mainly affecting the aragonitic representatives of the family Ceratobuliminidae) or significant recrystallization (Herrero and Canales, 2002), the last one affecting more intensively the Zambujal de Alcaria specimens. As a consequence, the specimens of foraminifera from this section are poorly preserved when compared with the specimens obtained in the Maria Pares section, as can be seen in figures 4, 5 and 6, where the most representative taxa are illustrated. In some assemblages, mostly in the Zambujal de Alcaria section, the total amount of 300 foraminifera was not achieved. Thus, in absence of taphonomic processes which could have affected the structure of the assemblages, such low number must be related to pale- oecological factors which may have played a significant role in the development of the communities.

From a taxonomical point of view, all the studied assemblages are typical of the upper Toarcian-middle Aalenian assemblages from carbonate platforms set in mid-paleolatitudes, in which the genus Lenticulina (suborder Lagenina) usually dominates (Barbieri, 1964; Bartenstein and Brand, 1937; Boutakiout, 1990; Canales, 2001; Canales and Henriques, 2008, 2013; Canales et al., 2010, 2014; Coleman, 1981; Grigelis and Norling, 1999; Henriques and Canales, 2013; Herrero and Canales, 1997; Stam, 1985; Tyszka, 1999; Wernli, 1971). In the section of Zambujal de Alcaria, the percentages of the suborders Textulariina and Spirillinina are relatively important, when compared to those of the remaining identified suborders, being the first one more abundant than the second one. In the section of Maria Pares, Lagenina is also the most abundant suborder. However, representatives of the suborder Miliolina, almost absent in the section of Zambujal de Alcaria, attaint important relative abundances in some assemblages. Representatives of the suborders Textulariina and Spirillinina have been obtained in almost all the studied assemblages from the section of Maria Pares, showing relative abundance lower than $13 \%$. Representatives of the suborder Robertinina can be considered minor components of the assemblages in both sections.

\subsection{Foraminiferal assemblages of the section of Maria Pares}

From the 17 studied samples, a total of 13,520 specimens were obtained, corresponding to 5 suborders, 12 families, 18 genera and 45 species (Fig. 2) (Canales et al., 2010; Guterres, 2010; Figueiredo and Guterres, 2012). The most representative forms are represented in figures 4,5 and 6 .

Recorded foraminiferal assemblages present a high relative abundance of the representatives of the suborder Lagenina $(90.2 \%)$, followed by representatives of suborders Miliolina (5.6\%) and Textulariina (3.5\%), the representatives of suborders Spirillinina $(0.6 \%)$ and Robertinina $(0.1 \%)$ being only minor components. At generic level, a high relative abundance of Lenticulina (75\%), followed by Astacolus (6.2\%), Vinelloidea (5.3\%), and Nodosaria (5\%) have been

Fig. 4.- (next page) Upper Toarcian and lower Aalenian selected foraminifera corresponding to the suborders Textulariina, Spirillinina, Miliolina and Lagenina. A, Thurammina jurensis (Franke) (MP-15.1.1), Toarcian, Aalensis Biozone, Aalensis Subzone; B, Ammobaculites coprolithiformis (Schwager) (MP-21.2.2), Toarcian, Aalensis Biozone, Aalensis Subzone; C, Ammobaculites fontinensis (Terquem) (MP-42.3.3), Aalenian, Opalinum Biozone, Opalinum Subzone; D, Ammobaculites vetustus (Terquem and Berthelin) (MP-3.1.47), Toarcian, Aalensis Biozone, Mactra Subzone; E, Trochammina cf. canningensis Tappan (ZB-18.3.3), Toarcian, Aalensis Biozone, Aalensis Subzone; F, Spirillina numismalis Terquem and Berthelin (MP-21.7.7), Toarcian, Aalensis Biozone, Aalensis Subzone; G, Spirillina orbicula Terquem and Berthelin (MP21.8.8), Toarcian, Aalensis Biozone, Aalensis Subzone; H. Vinelloidea tibia (Terquem and Berthelin) (MP-3.5.5), Toarcian, Aalensis Biozone, Mactra Subzone; I, Ophthalmidium carinatum (Kübler and Zwingli) (MP-3.9.10), Toarcian, Aalensis Biozone, Mactra Subzone; J, Ophthalmidium concentricum (Terquem and Berthelin) (MP-6.10.11), Toarcian, Aalensis Biozone, Mactra Subzone; K, Lingulonodosaria dentaliniformis (Terquem). (MP-58.11.12), Aalenian, Opalinum Biozone, Comptum Subzone; L, Prodentalina propinqua (Terquem) (MP-15.12.13), Toarcian, Aalensis Biozone, Aalensis Subzone; M. Prodentalina pseudocommunis (Franke) (MP-29.13.14), Toarcian, Aalensis Biozone, Aalensis Subzone; N, Prodentalina subsiliqua (Franke) (MP-14.14.15), Toarcian, Aalensis Biozone, Aalensis Subzone; O. Prodentalina varians (Terquem) (MP-29.3.49), Toarcian, Aalensis Biozone, Aalensis Subzone; P, Falsopalmula jurensis (Franke) (MP-42.15.17), Aalenian, Opalinum Biozone, Opalinum Subzone. Scale: $100 \mu$. 

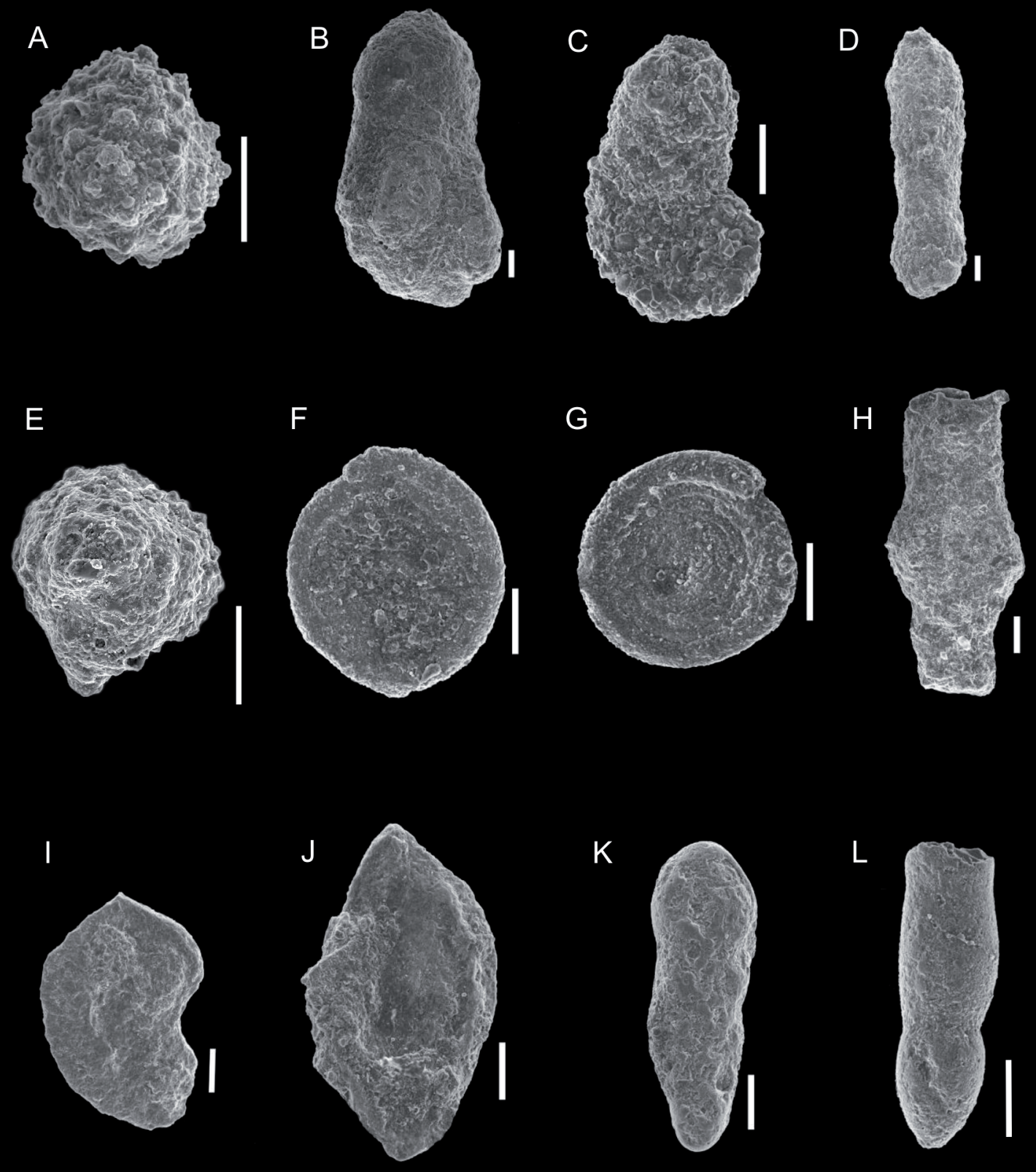

K
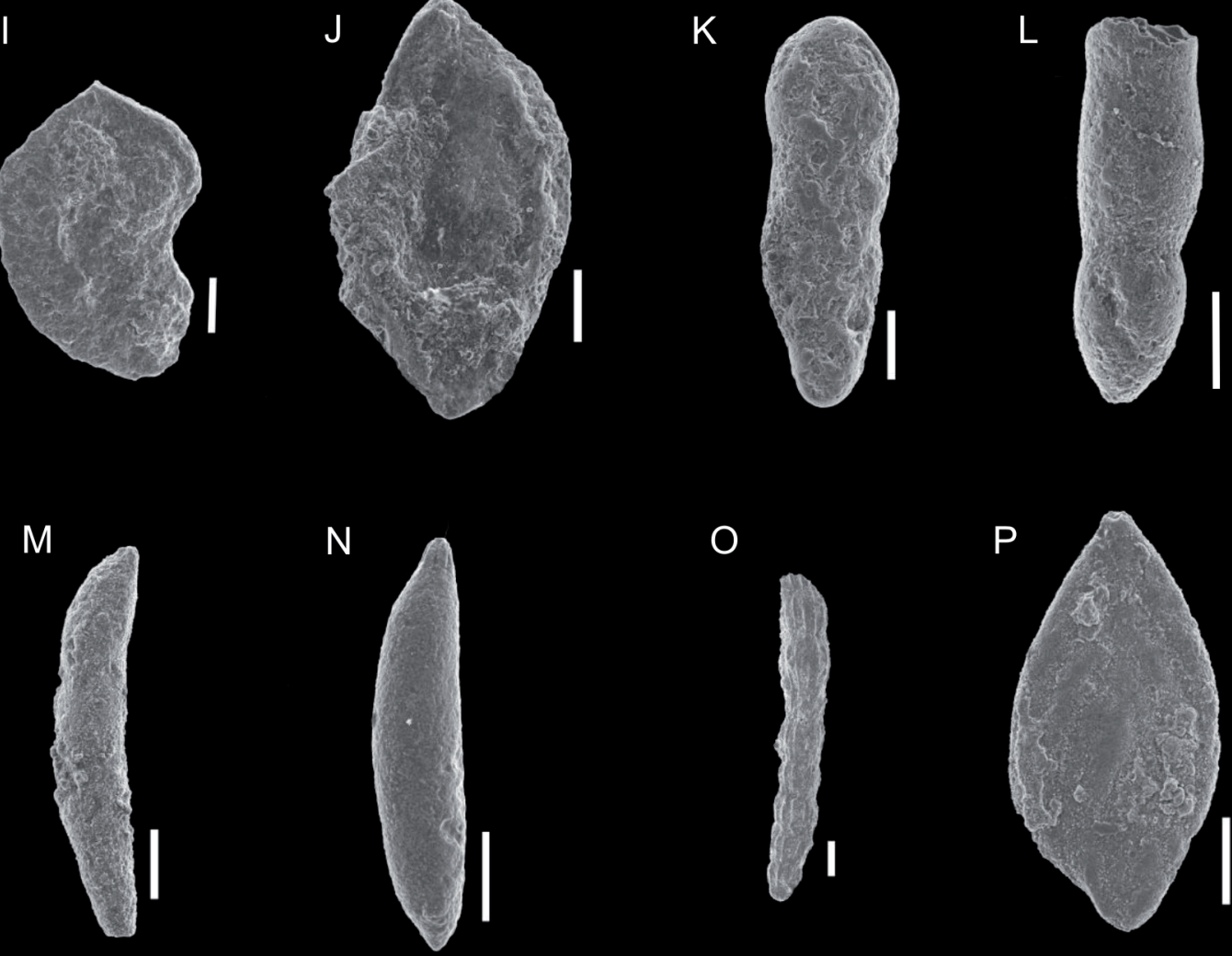

o

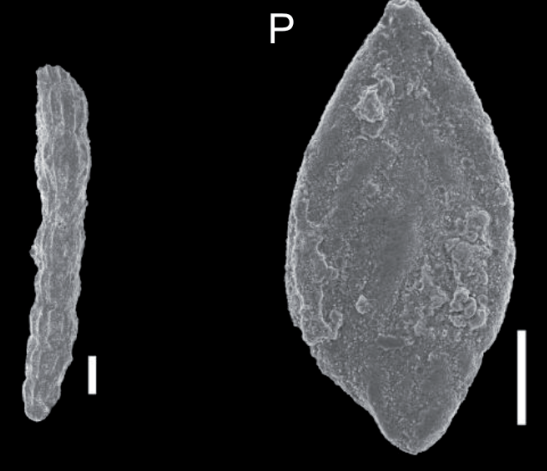


observed in all the assemblages. At specific level, Lenticulina toarcense (Payard) is the most abundant (3,834 specimens; $28.4 \%$ ) in almost all of them. Lenticulina helios (Terquem) and Lenticulina polygonata (Franke) are also very abundant (1,469 and 1,232 specimens, respectively; $10.9 \%$ and $9.1 \%)$.

The highest number of species has been recorded in the Aalensis (36 species) and the Opalinum (also 36 species) subzones, but the assemblage displaying higher amount of identified species (MP-3) corresponds to the Mactra Subzone. On the other hand, assemblages from MP-60 and MP-65/66, corresponding to the upper part of the Comptum Subzone, yield the lowest amount of species (12 and 11 respectively).

Across the studied stratigraphic interval, the most characteristic Lower Jurassic taxa show a progressive replacement by Middle Jurassic forms (Fig. 2). The first appearance datum (FAD) of Prodentalina propinqua (Terquem), Nodosaria torulosi Frentzen, Prodentalina varians (Terquem), Citharina heteropleura (Terquem), Spirillina numismalis Terquem and Berthelin and Thurammina jurensis (Franke) occur in the Aalensis Subzone; the FAD of Planularia beierana (Gümbel), Nodosaria sp. 1 Canales, Reinholdella dreheri (Bartenstein) and Lenticulina cf. quenstedti (Gümbel) has been recorded in the Opalinum Subzone, and the FAD of Lingulonodosaria dentaliniformis (Terquem) occurs in the Comptum Subzone. Among the last appearance datum (LAD), the most significant of them occur in the Comptum Subzone: Eoguttulina liassica (Strickland), Planularia cordiformis (Terquem), Prodentalina subsiliqua (Franke), Prodentalina pseudocommunis (Franke), Astacolus dorbignyi (Roemer), Planularia protracta (Bornemann) and Nodosaria liassica Barnard.

\subsection{Foraminiferal assemblages of the section of Zambu- jal de Alcaria}

From the 20 studied samples, a total of 5,291 specimens were obtained, corresponding to 5 suborders, 13 families, 25 genera and 51 species (Fig. 3) (Figueiredo, 2009; Canales et al., 2010; Figueiredo et al., 2010a, 2010b). The most representative forms are represented in figures 4, 5 and 6.

The assemblages are dominated by representatives of the suborder Lagenina (90\%), followed by Textulariina (6.1\%), Spirillinina $(2.3 \%)$ and very scarce representatives of sub- orders Miliolina (1.3\%) and Robertinina (0.3\%). The most abundant genus is Lenticulina $(82.7 \%)$, followed by Astacolus (4.6\%), Nodosaria (4.5\%), and Ammobaculites (2.5\%). As in the Maria Pares section, Lenticulina toarcense Payard is the most abundant species (1,785 specimens; $33.7 \%)$ in all the assemblages, followed by Lenticulina helios (Terquem) and Lenticulina muensteri (Roemer) (497 and 464 specimens, respectively; $9.4 \%$ and $8.8 \%$ ).

The highest amount of recorded species (33) in the whole section was recorded in the assemblage ZB-18, corresponding to the Aalensis Subzone. The most abundant species were recognized in almost all the assemblages, but the Opalinum Subzone records the highest amount of species (34) of the whole section. On the contrary, several assemblages of this section yielded a low number of specimens and species, such as ZB-10 (9 species) from the Mactra Subzone, ZB-12 (9 species) and ZB-28 (4 species) from the Aalensis Subzone, ZA20 (8 species) and ZA-90 (10 species) from the Comptum Subzone. The only studied assemblage of the Bradfordensis Subzone is constituted by a small amount of specimens (12), which correspond to 8 previously identified species.

Also worth noting in this section is the high number of species (17) that present a record restricted to a single assemblage (Fig. 3), mainly in the Aalensis Subzone, as well as the record of some species that have been only identified in the Zambujal de Alcaria section, being absent in other coeval sections in the Lusitanian Basin, where they have not been found so far. That is the case of Pseudonodosaria cf. rapiformis (Franke), Marginulinopsis cf. major (Bornemann), Ophthalmidium cf. carinatum (Kübler and Zwingli), Conicospirillina sp. indet., Spirophthalmidium cf. clarum Antonova, Vaginulina listi (Bornemann), Lagena tenuicostata Franke and Lamarckella cf. inflecta Kaptarenko-Chernousova.

\subsection{Paleoecological analysis}

In order to substantiate the paleoecological interpretation, qualitative and quantitative analysis, based on relative abundance at different taxonomical levels, and several diversity indexes calculated for each assemblage in both sections, were carried out. Variations in the obtained values throughout the

Fig. 5.- (next page) Upper Toarcian and lower Aalenian selected foraminifera corresponding to the suborder Lagenina. A, Falsopalmula tenuistriata (Franke) (MP-3.16.18), Toarcian, Aalensis Biozone, Mactra Subzone; B, Falsopalmula sp. 1 Canales (ZB-18.9.9), Toarcian, Aalensis Biozone, Aalensis Subzone; C, Nodosaria fontinensis Terquem (MP-3.17.19), Toarcian, Aalensis Biozone, Mactra Subzone; D, Nodosaria hortensis Terquem (MP-21.18.20), Toarcian, Aalensis Biozone, Aalensis Subzone; E, Nodosaria liassica Barnard (MP-58.19.22), Aalenian, Opalinum Biozone, Comptum Subzone; F, Nodosaria pseudoregularis Canales (MP-21.20.23), Toarcian, Aalensis Biozone, Aalensis Subzone; G, Nodosaria pulchra (Franke) (MP-47.21.24), Aalenian, Opalinum Biozone, Opalinum Subzone; H, Nodosaria torulosi Frentzen (MP21.22.25), Toarcian, Aalensis Biozone, Aalensis Subzone; 9, Nodosaria sp. 1 Canales (MP-47.23.26), Aalenian, Opalinum Biozone, Opalinum Subzone; I, Pseudonodosaria vulgata (Bornemann) (MP-37.24.27), Aalenian, Opalinum Biozone, Opalinum Subzone; J, Lenticulina bochardi (Terquem) (MP-15.3.49), Toarcian, Aalensis Biozone, Aalensis Subzone; K, Lenticulina constricta (Kaptarenko-Chernousova) (ZB-18.15.15), Toarcian, Aalensis Biozone, Aalensis Subzone; L, Lenticulina exgaleata Dieni (MP-26.27.30), Toarcian, Aalensis Biozone, Aalensis Subzone; M, Lenticulina helios (Terquem) (MP-48.5.51), Aalenian, Opalinum Biozone, Comptum Subzone; O, Lenticulina muensteri (Roemer) (MP26.29.32), Toarcian, Aalensis Biozone, Aalensis Subzone. P, Lenticulina polygonata (Franke) (MP-26.30.33), Toarcian, Aalensis Biozone, Aalensis Subzone. Scale: $100 \mu$. 

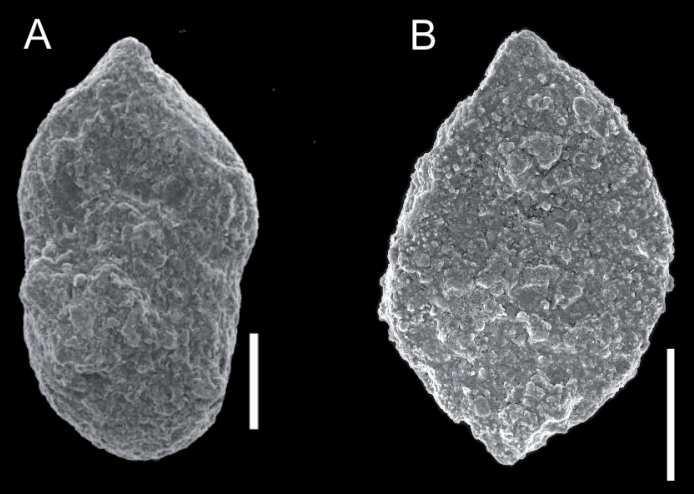

C

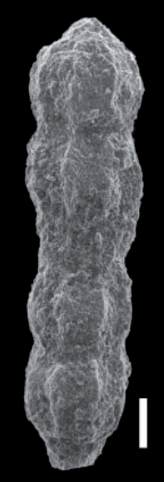

E
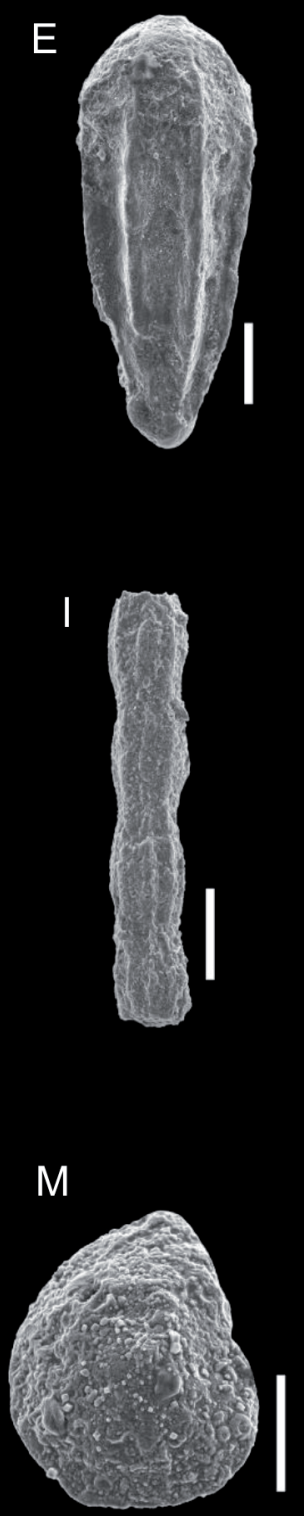

F
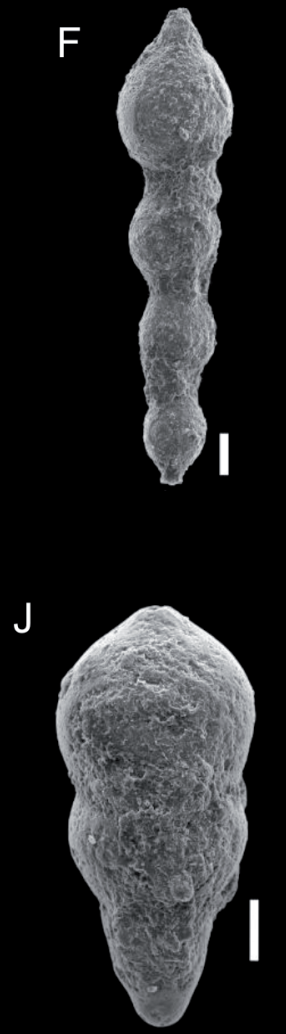

K
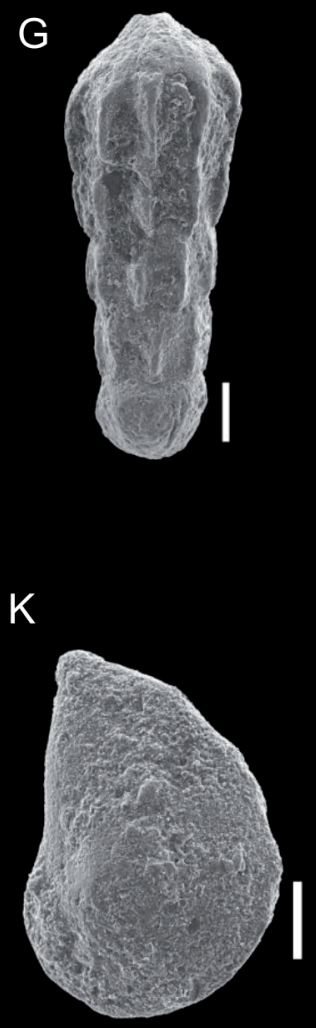

I

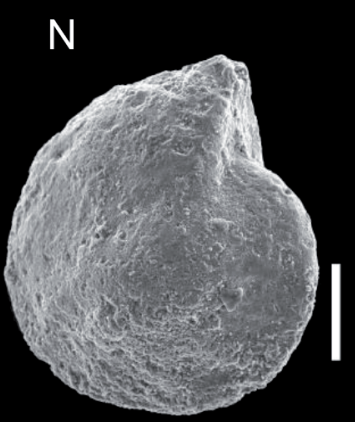

0

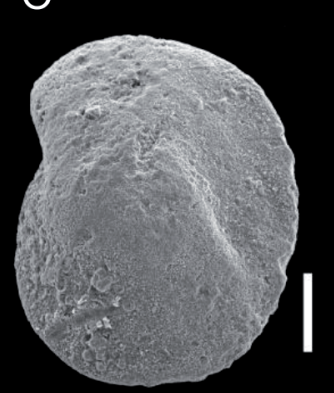

D

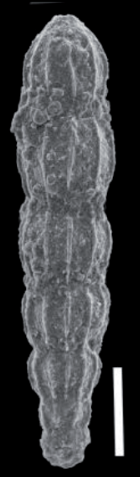

$\mathrm{H}$

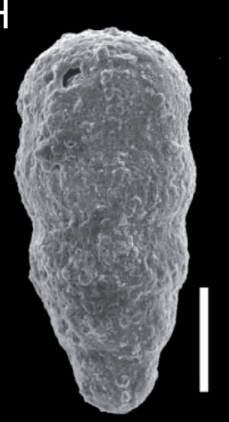

$\mathrm{L}$

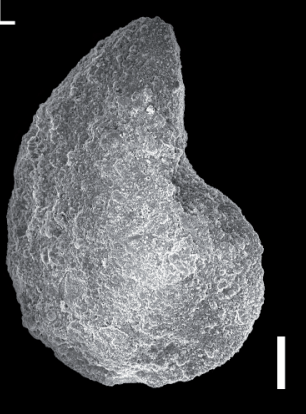

$\mathbf{P}$

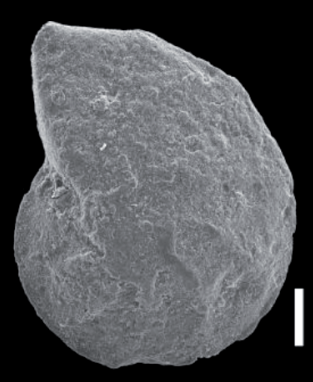


studied stratigraphic interval in both sections were interpreted and compared.

In the section of Maria Pares, the number of specimens obtained in each sample is quite variable, from 1,747 to 64 , and the number of species ranges between 33 and 11. In the section of Zambujal de Alcaria, the number of specimens obtained in each sample varies from 547 to 12 , and the number of species ranges between 33 (like in the Maria Pares section) and 4.

Values of Fisher's $\alpha$ diversity index vary between 3.53 and 6.76 in the Maria Pares section (Fig. 7A) and between 2.25 and 7.72 in the Zambujal de Alcaria section (Fig. 8A), where an unusual high value of this index (16.4) was observed in sample ZA-94 due to the low number of obtained specimens (12) corresponding to a high number of species (9). In both sections, values of this index are relatively low and irregular from the Mactra Subzone until the lower part of the Opalinum Subzone, but in Zambujal de Alcaria the irregularity of the values is much more marked than in Maria Pares. In both sections, the values are high and quite homogeneous in the lower Aalenian (Opalinum Biozone), but in the upper part of the Comptum Subzone to the lower part of the Bradfordensis Subzone values decrease. Thus, comparison between the obtained values of this index shows that they are quite similar and general trends in both sections along the studied stratigraphic interval are the same.

Values of richness obtained from Margalef's index oscillate between 2.46 and 4.72 in the assemblages of the Maria Pares section (Fig. 7B), and between 1.4 and 5.1 in the assemblages of the Zambujal de Alcaria section (Fig. 8B). Trends observed are similar to the Fisher's $\alpha$ index, i.e. values are low in the section of Maria Pares and irregular in the section of Zambujal de Alcaria assemblages from the Mactra Subzone to the lower part of the Opalinum Subzone, they increase and stay relatively homogeneous in both sections along the Opalinum Biozone, and finally they show a decrease across the Opalinum-Bradfordensis Biozone transition. Comparison between the obtained values in both sections shows again that they are comparable and their general trends remain similar.

Values of the Simpson index oscillate between 0.69 and 0.91 in the section of Maria Pares (Fig. 7C) and between 0.6 and 0.9 in the section of Zambujal de Alcaria (Fig. 8C), being very similar in both sections. In the first one, values of this index show a slight decreasing trend upwards, from the Mactra Subzone to the lower part of the Opalinum Subzone while they are more irregular in Zambujal de Alcaria for the same time span. In both sections, the values of Simpson index are higher throughout most of the Opalinum Biozone, but in the upper part of the Comptum Subzone to the lower part of the Bradfordensis Subzone they decrease. Comparison between both sections shows that the values obtained display again the same general trends.

Values of the Berger-Parker index show variations between 0.20 and 0.53 in the section of Maria Pares (Fig. 7D) and between 0.25 and 0.61 in the section of Zambujal de Alcaria (Fig. 8D). Such values, as well as the observed trends in values variations throughout the studied stratigraphic interval are very similar to the values of Simpson index previously referred.

Concerning the values of Shannon-Wiener index, they are quite regular in both studied sections, Maria Pares (between 1.71 and 2.76, Fig. 7E) and Zambujal de Alcaria (between 1.37 and 2.5, Fig. 8E). Again, and according to values variations of this index, trends observed are similar in the two sections and to Simpson and Berger-Parker indexes values previously described.

Values of the Pielou's equitability vary between 0.53 and 0.79 in the section of Maria Pares (Fig. 7F) and between 0.6 and 0.95 in the section of Zambujal de Alcaria (Fig. 8 F). In general, higher values of equitability were obtained in Zambujal de Alcaria when compared to the Maria Pares data. Again, from the Mactra Subzone to the lower part of the Opalinum Subzone the values in the Maria Pares section display a decreasing trend, whilst they are irregular in the Zambujal de Alcaria section. In both sections, all values keep constant throughout most of the Opalinum Biozone, and from the upper part of the Comptum Subzone to the lower Bradfordensis Subzone, values decrease again.

\section{Discussion}

As benthic foraminifera, due to their environmental preferences, are strongly linked to paleoecological conditions where they can develop, the taxonomical composition and diversity of the assemblages, in absence of taphonomic

Fig. 6.- (next page) Upper Toarcian and lower Aalenian selected foraminifera corresponding to the suborders Lagenina and Robertinina. A, Lenticulina toarcense Payard (MP-15.6.52), Toarcian, Aalensis Biozone, Aalensis Subzone; B, Marginulinopsis pennensis (Cubaynes and Ruget) (MP-3.32.35), Toarcian, Aalensis Biozone, Mactra Subzone; C, Saracenaria sp. indet. (ZB-34.23.23), Aalenian, Opalinum Biozone, Opalinum Subzone; D, Astacolus dorbignyi (Roemer) (MP-26.4.50), Toarcian, Aalensis Biozone, Aalensis Subzone; E, Astacolus scalptus (Franke) (MP-26.25.28), Toarcian, Aalensis Biozone, Aalensis Subzone; F, Astacolus varians (Bornemann) (MP-21.35.38), Toarcian, Aalensis Biozone, Aalensis Subzone; G, Citharina clathrata (Terquem) (MP-44.37.29), Aalenian, Opalinum Biozone, Opalinum Subzone; H, Citharina colliezi (Terquem) (MP-26.38.40), Toarcian, Aalensis Biozone, Aalensis Subzone; I, Citharina heteropleura (Terquem) (MP-26.36.39), Toarcian, Aalensis Biozone, Aalensis Subzone; J, Planularia beierana (Gümbel) (MP-37.39.41), Aalenian, Opalinum Biozone, Opalinum Subzone; K, Planularia cordiformis (Terquem) (MP-21.40.42), Toarcian, Aalensis Biozone, Aalensis Subzone; L, Planularia protracta (Bornemann) (MP-44.5.51), Aalenian, Opalinum Biozone, Opalinum Subzone; M, Vaginulina listi (Bornemann) (ZB-18.26.26), Toarcian, Aalensis Biozone, Aalensis Subzone; N, Eoguttulina liassica (Strickland) (MP-48.6.52), Aalenian, Opalinum Biozone, Comptum Subzone; O, Bullopora globulata Barnard and Bullopora rostrata Quenstedt (ZB-34.29.29), Aalenian, Opalinum Biozone, Opalinum Subzone; P, Ceratobuliminidae sp. indet. (ZB-18.32.32), Toarcian, Aalensis Biozone, Aalensis Subzone. Scale: $100 \mu$. 
A

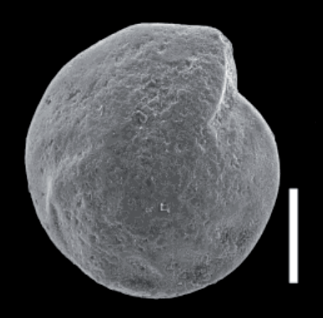

B
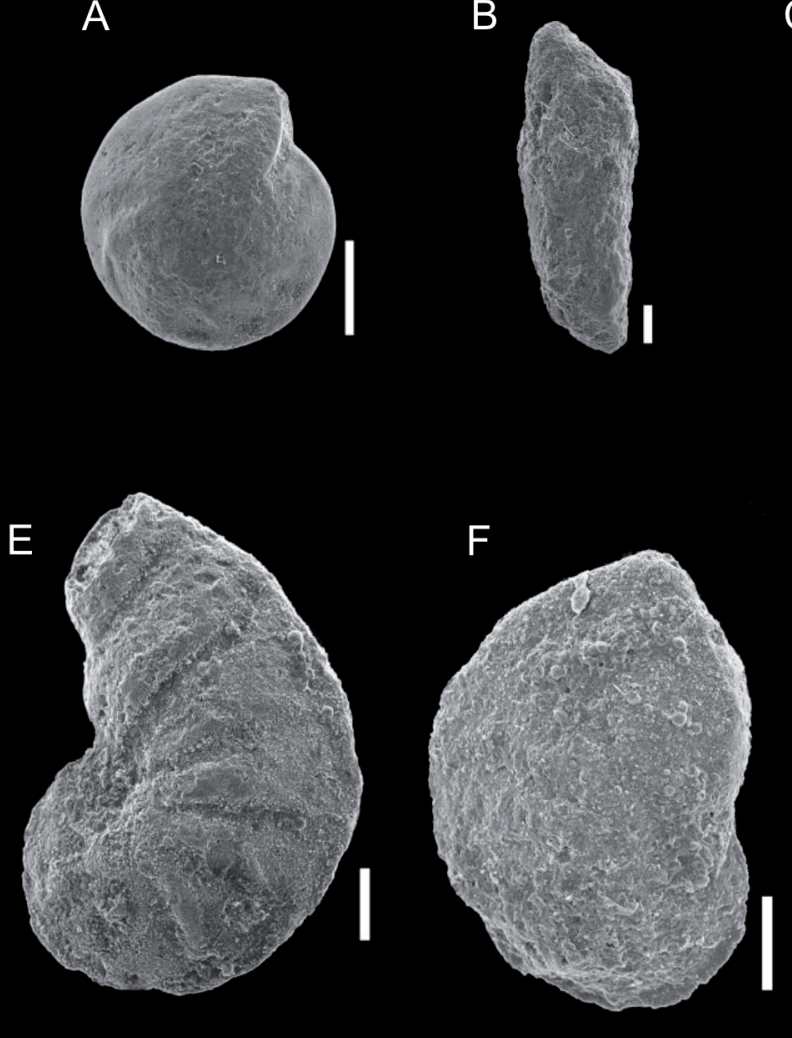

D

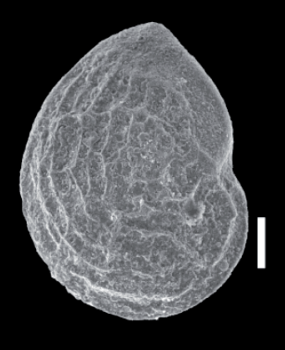

G
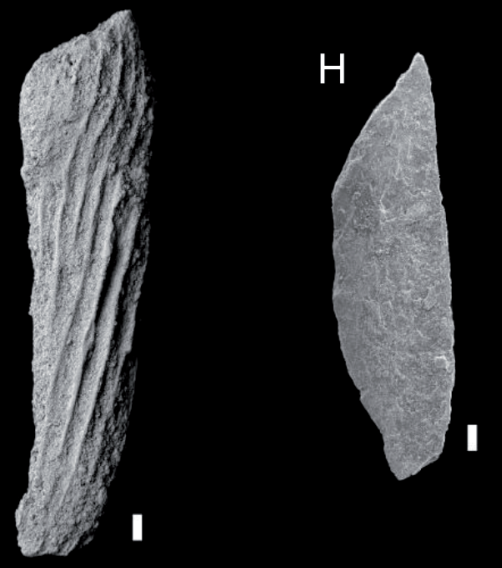
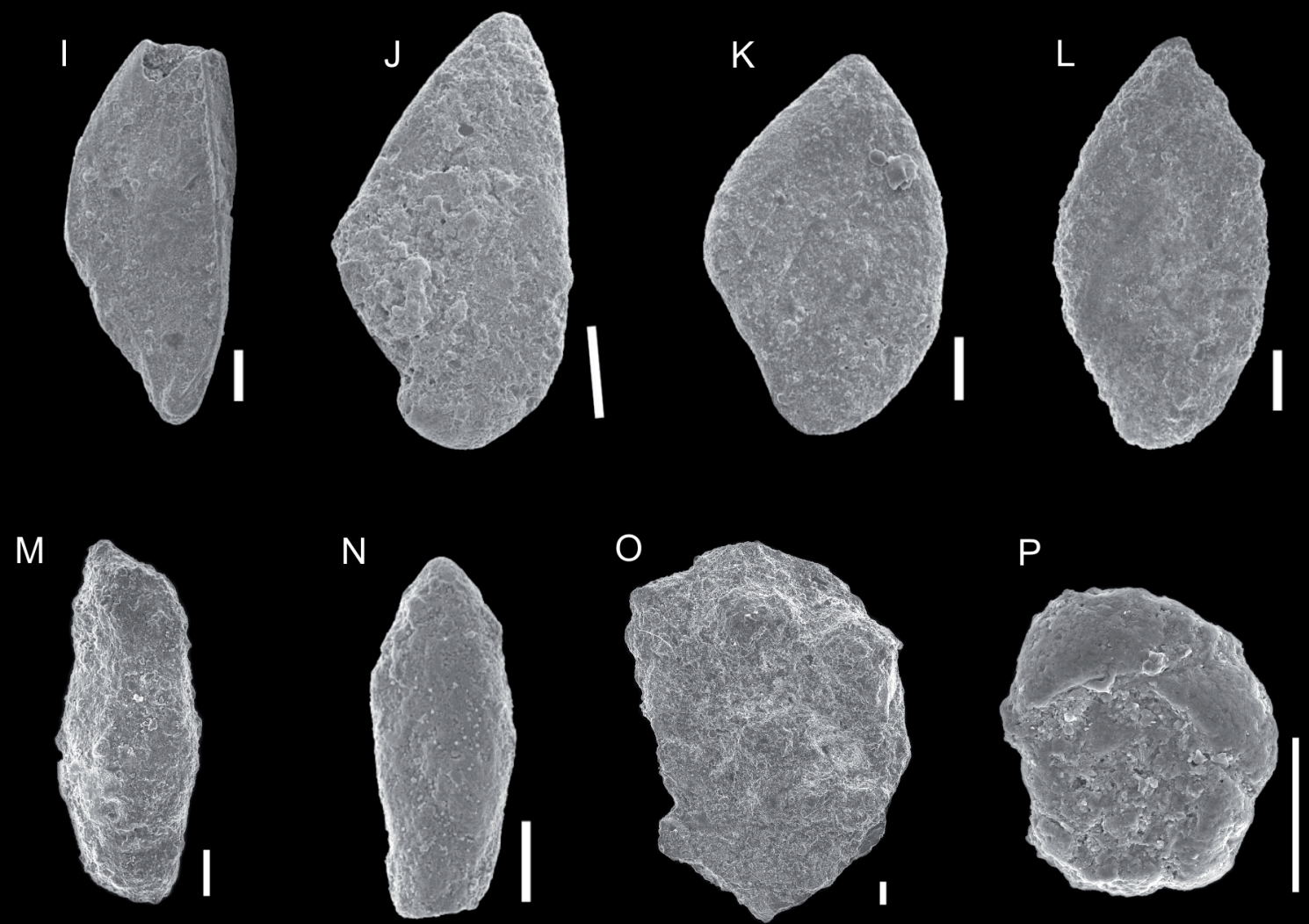
changes, must reflect some of such environmental parameters, such as water temperature, oxygen level, food supply, etc. Thus, abundant (high number of specimens) and diverse (high number of taxa) assemblages, showing no dominance of any taxon and displaying high levels of equitability would reflect appropriate environmental conditions for the development of this group. In addition, quantitative approaches to the foraminiferal assemblages recorded from a specific stratigraphic interval, enabling the determination of relative abundances or the use of numerical indexes expressing diversity, dominance and equitability, provide strong evidence to support interpretations concerning the evolution of the paleoenvironmental conditions in a particular area during the considered time span.

\subsection{Taxonomical composition of the assemblages}

The taxonomical composition of the assemblages in the studied sections is comparable to other coeval sections located in the Iberian Peninsula (Herrero and Canales, 1997; Canales and Herrero, 2000; Canales, 2001; Canales and Henriques, 2007, 2008; Henriques and Canales, 2013). They are constituted by typical taxa of the Boreal Realm, on which representatives of the suborder Lagenina are the most abundant components (Haynes, 1981; Murray, 1989), usually accompanied by variable percentages of representatives of the suborders Textulariina, Spirillinina, Miliolina, Robertinina and Rotaliina depending on paleoecological conditions.

According to Johnson (1976), in the Jurassic carbonate platforms the representatives of the suborder Lagenina attaint the maximum diversity in the middle and inner part of the platforms. In the Lusitanian Basin, where paleogeographical position of the studied sections, as well as other coeval sections like São Gião and Murtinheira, is well known, this interpretation is reinforced by the small number of species corresponding to this suborder referred in Murtinheira (Canales and Henriques, 2007, 2008; Canales et al., 2010, 2014) when compared to data obtained for increasingly proximal sections like São Gião (Henriques and Canales, 2013), Maria Pares and Zambujal de Alcaria.

On what concerns the other identified suborders of the studied assemblages, some differences can be recognized between both sections. Representatives of the suborder Miliolina are relatively important components in the assemblages from Maria Pares (5.6\%), but display low relative abundances in Zambujal de Alcaria (1.3\%). On the other hand, representatives of the suborder Textulariina are more abundant in the Zambujal de Alcaria section (6.1\%) when compared to the Maria Pares section (3.5\%). In coeval assemblages obtained in the section of Murtinheira, the second most abundant component are the representatives of the suborder Spirillinina (Canales and Henriques, 2007, 2008), whereas in the assemblages of the section of São Gião the suborder Miliolina attaints high relative abundances, like in the section of Maria Pares, being the most abundant in some assemblages (Henriques and Canales, 2013). So, a gradient at the suborder level seems to exist in the Lusitanian Basin, the representatives of suborder Spirillinina showing the highest relative abundances in the distal part of the platform (Murtinheira), whereas representatives of suborder Miliolina show their maximum relative abundance in the middle part of the platform (sections of Maria Pares and São Gião), and representatives of suborder Textulariina display their maximum relative abundance in the proximal part of the shelf (in the Zambujal de Alcaria section).

A relationship between the relative abundance of these suborders and the paleoecological conditions where they developed has been pointed out by several authors. Johnson (1976), Haynes (1981), Morris and Coleman (1989) and Nagy et al. (1990) have noted that the representatives of the suborder Lagenina dominated the foraminiferal assemblages developed in the Jurassic platforms from the northern hemisphere when normal marine salinity, accompanied by normal levels of oxygenation conditions occur, whereas under low oxygen levels foraminiferal assemblages are dominated by agglutinated forms (representatives of the suborder Textulariina) accompanied by a low number of calcareous smoothwall taxa (Scheibnerová, 1968; Murray, 1989; Tyszka, 1994b). Agglutinated forms are also dominant components in assemblages developed under low salinity conditions, as in proximal marine environments, especially when fluvial influence takes place, where such assemblages display a low diversity (Murray, 1989; Nagy and Johansen, 1991; Nagy, 2005; Ghandour and Maejima, 2007). Concerning the representatives of the suborder Miliolina, they have been related with warm waters (Copestake and Johnson, 1981; Haynes, 1981; Murray, 1989), attaining up to $40 \%$ in assemblages from subtropical temperatures (Alegret, 2004). Paleoecological interpretations related to the representatives of suborder Spirillinina link them to a wide variety of conditions. They have been considered as indicators of normal marine conditions, relatively shallow and well-oxygenated (Murray, 1989; Stam, 1985), whereas Tyszka (2001) pointed out that they can occur in a wide variety of environments but are dominant in assemblages from inner to middle neritic zones. Canales (2001) and Canales and Henriques (2008) instead related the high relative abundance of this suborder with deeper conditions.

At a generic level, Lenticulina is the most abundant genus not only in the studied sections but also in coeval stratigraphic intervals from other sections located in the Lusitanian Basin, in the Basque-Cantabrian Basin and in the Iberian Basin. This fact maybe due to its ability to colonize a great variety of substrates, as pointed by Haynes (1981) who indicates that this genus is in general the dominant taxon in the assemblages of Middle and Late Jurassic. In the same way, Tyszka (1994a) indicates that during Jurassic times, Lenticulina covers a broad range of habitats, developing different modes of life, from deep infaunal to shallow infaunal and even epifaunal. Studies carried out in different sections in the upper 


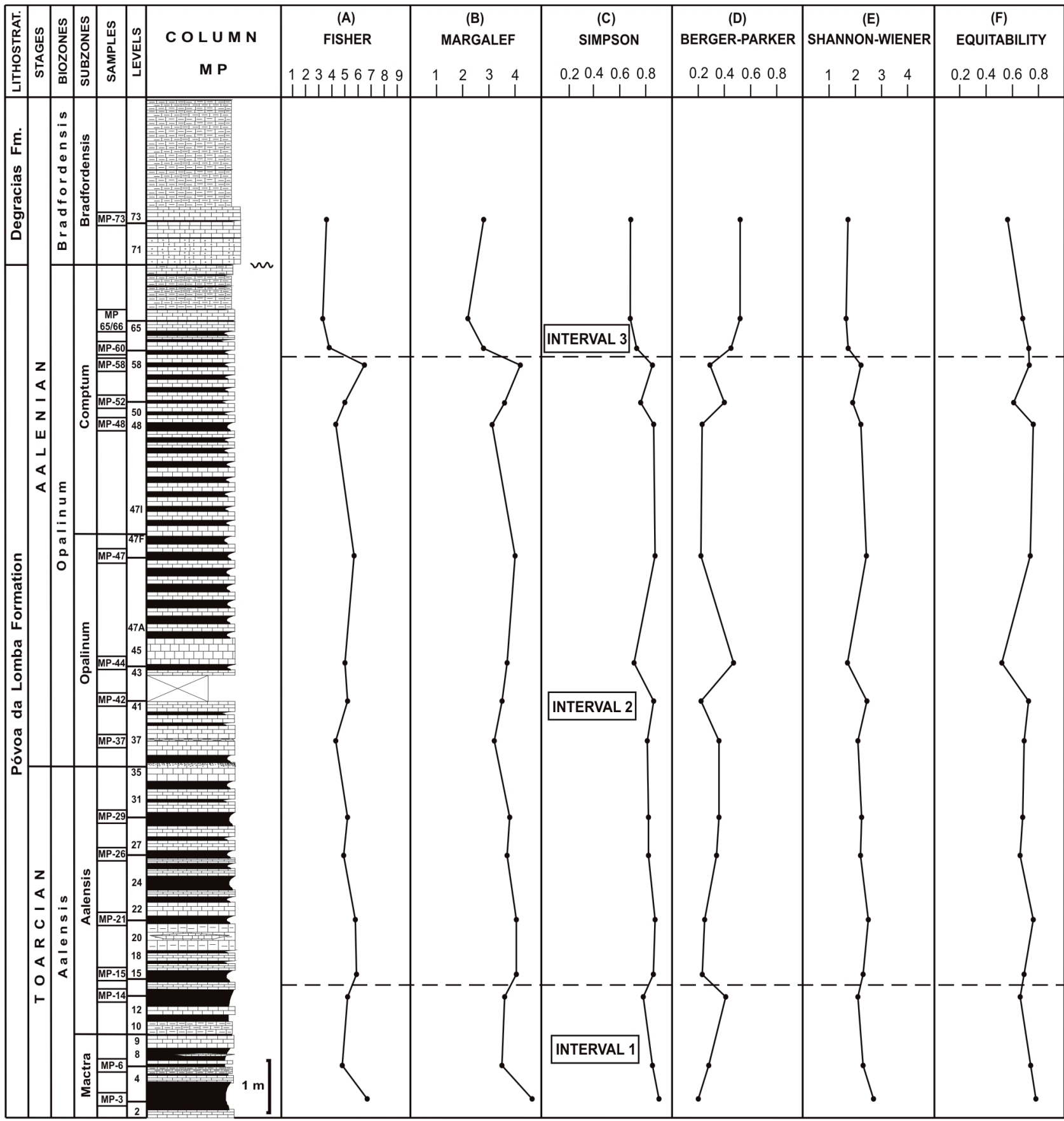

LEGEND

Limestone

Marls 䛓 Marly limestone

$\triangle$ Covered

MP.3 Samples

$\sim$ Discontinuity

Fig. 7.- Obtained values of the diversity indexes in the Maria Pares section and identified intervals established from their variations. (A) Fisher's $\alpha$ diversity index; (B) Margalef's richness index; (C) Simpson index; (D) Berger-Parker index; (E) Shannon-Wiener index; (F) Pielou's equitability.

Toarcian-lower Aalenian of the Lusitanian Basin, located in the distal, middle and inner part of the platform (Canales and Henriques, 2008, 2013; Canales et al., 2010, 2014; Figueiredo et al., 2010a; Henriques and Canales, 2013), confirm this fact, as to this genus corresponds the higher values of relative abundance in almost all the analyzed assemblages. The high values of this genus, corresponding to a lenticular morphogroup (Nagy, 1992; Tyszka, 1994a; Reolid et al., 2008,
2012, 2013), indicate that the studied assemblages developed in oxic environmental conditions. This reinforces previous interpretations supported by the taxonomical composition analysis at suborder level. Communities that lived in anaerobic environments are considered to be constituted by calcareous taxa corresponding to other morphogroups (Bernhard, 1986; Tyszka, 1994b) and generally include a high proportion of agglutinated forms (Scheivnerová, 1968; Tyszka, 1994b). 


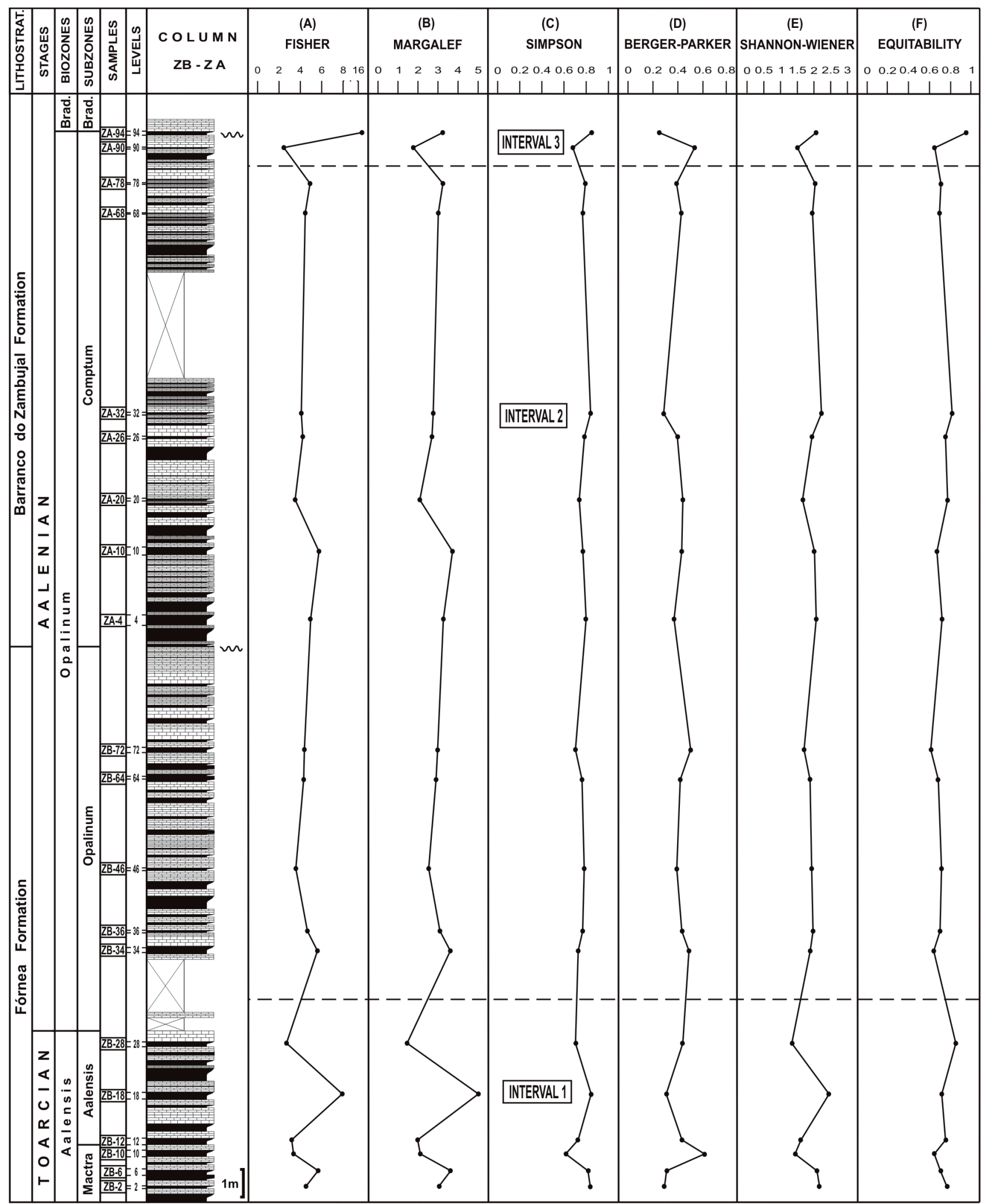

LEGEND

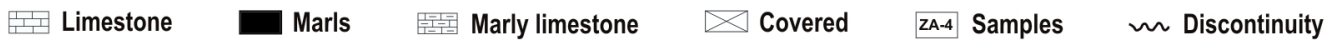

Fig. 8.- Obtained values of diversity indexes in the Zambujal de Alcaria section and identified intervals established from their variations. (A) Fisher's $\alpha$ diversity index; (B) Margalef's richness index; (C) Simpson index; (D) Berger-Parker index; (E) Shannon-Wiener index; (F) Pielou's equitability. 
Other genera displaying high relative abundance in the studied assemblages are Nodosaria in the section of Zambujal de Alcaria, and Vinelloidea in the section of Maria Pares. Murray (1989) argues that foraminiferal assemblages of Middle Jurassic shallow carbonate environments are dominated by Lenticulina, Citharina and Nodosaria. The high relative abundance of Nodosaria in the assemblages of the Zambujal de Alcaria section matches the sedimentological data that point out the proximal position of this section within the Lusitanian Basin for the considered stratigraphic interval. In the section of Maria Pares the second most abundant genus is Vinelloidea (suborder Miliolina) that has already been emphasized by Henriques and Canales (2013) for a neighbouring coeval interval in the section of São Gião, as a result of relatively high warm seawater temperature interpreted as due to local causes. In the Maria Pares section other genera showing high relative abundance are Astacolus and Nodosaria, being Astacolus a very common constituent in the foraminiferal assemblages of coeval stratigraphic intervals in other sections from the Iberian Plate. Spirillina shows relatively low abundance in the studied sections, unlike data described for the section of Murtinheira (Canales and Henriques, 2007, 2008), where it is the second most abundant taxon, a fact interpreted by Canales (2001) in the Basque-Cantabrian Basin (N Spain), which may be related to deep conditions.

At specific level, in the Lusitanian Basin, the maximum diversity in the foraminiferal assemblages from Lower-Middle Jurassic transition was recognized in the section of São Gião, located in the middle part of the platform, where a total of 71 species were identified (Henriques and Canales, 2013), whilst in the section of Murtinheira, at the distal part of the platform, only 35 species were recognized for this stratigraphic interval (Canales and Henriques, 2007, 2008). This means a smaller amount of taxa when compared to the higher amount of taxa (45 and 51 species) recorded in the Maria Pares and Zambujal de Alcaria sections, respectively. In coeval stratigraphic intervals located in other basins of the Iberian Peninsula, a similar number of species than in the studied sections were identified. In the Basque-Cantabrian Basin, a total of 50 species were identified from a coeval stratigraphic interval in 7 sections (Canales, 2001), 47 species were recognized in the section of Moyuela (Canales and Herrero, 2000), located in the NE Iberian Range (western part of the so called "Arcos Plateau", Aragonese Platform) and 62 species in the section of Fuentelsaz (Herrero and Canales, 1997), in the central Iberian Range (Castilian Platform) being the type locality for the Aalenian GSSP (Cresta et al., 2001).

At specific level, the identified species are in most cases the same. However, there are some differences between the sections regarding the relative abundance of some of them. The species with the highest relative abundance recorded in the Maria Pares section is the same as in the Zambujal de Alcaria section (Lenticulina toarcense Payard), whereas in the section of São Gião is Lenticulina helios (Terquem) (Henriques and Canales, 2013) and in the section of Murtinheira the most abundant species is Lenticulina muensteri (Roemer) (Canales and Heriques, 2007; 2008; Canales et al., 2010).

Taking these interpretations into account, as well as the previous stratigraphic data of the Lusitanian Basin, and considering the taxonomical composition of the foraminiferal assemblages obtained in the studied sections, it is possible to assume that the communities developed in normal marine conditions under appropriate levels of salinity and oxygenation. The relative high abundance of the representatives of suborder Textulariina would be related with the proximal position of the Zambujal de Alcaria section in the basin. To explain the high relative abundance of the representatives of the suborder Miliolina in the Maria Pares section, located in the middle part of the shelf, warmer water conditions must be invoked, as previously argued by Henriques and Canales (2013) in the near locality of São Gião, where representatives of the suborder Miliolina attaint relative abundances up to $76 \%$. They are accompanied by demic ammonite assemblages including abundant Mediterranean Grammoceratinae (Ammonitina), also related to warm seawater temperature.

The occurrence of both groups in this section has been interpreted as linked to local conditions related with the paleogeographical location in the context of the opening of the North Atlantic Ocean and/or the paleoceanographic currents, or even to hydrothermal activity. It should be noted that in coeval stratigraphic interval in the Basque-Cantabrian Basin (N Spain), representatives of this suborder have never been found (Canales, 2001), only one specimen having been found in the section of Fuentelsaz (Aalenian GSSP type locality) in the central Castillian Platform (Iberian Range) which further supports the local nature of the warm seawater temperatures inferred for this area of the Lusitanian Basin.

\subsection{Diversity indexes}

Concerning the Fisher's $\alpha$ diversity index, Murray (1991) indicates that high values of this index are characteristic of normal marine environment, holding adequate conditions for the development of the foraminiferal assemblages, whereas low values may reflect environmental conditions that would inhibit the normal development of the assemblages. Data obtained are in general similar in both studied sections, reflecting in most cases relative good environmental conditions for the development of foraminiferal communities. However, the recorded trends of the value of this index, and of all other, (the Margalef's richness index, Simpson index, Berger-Parker index, Shannon-Wiener index and Pielou's equitability) allow the recognition of three episodes which would reflect different paleoecological conditions across the studied stratigraphic interval. Along the Mactra Subzone until the lower part of the Opalinum Subzone the obtained values reflect that such conditions were more unstable in the area of Zambujal de Alcaria (with irregular values) when compared to the area 
of Maria Pares, where values are more regular. Across lower Aalenian (Opalinum Biozone), environmental conditions must have become favourable and stable in both proximal and middle part of the platform, due to the high score and regularity of the values, but in the upper part of the Comptum Subzone and in the lower part of the Bradfordensis Subzone where lower values are reached in both sections, such conditions must have been unfavourable for the development of the foraminiferal communities.

Regarding the Margalef's richness index, values obtained in both sections show the same path as the Fisher's $\alpha$ index. In the section of Murtinheira values obtained in the Mactra Subzone until the lower part of the Comptum Subzone are irregular as in the Zambujal de Alcaria and Maria Pares sections. Along the Comptum Subzone values obtained in the section of Murtinheira are also higher and homogeneous, supporting favourable and stable environmental conditions for the development of the foraminiferal assemblages, and in the lower-middle Aalenian transition, values at Murtinheira also display a decreasing trend (Canales and Henriques, 2007, 2008).

Values of the Simpson index varies between 0 and 1 reflecting the diversity in an assemblage. When all the specimens correspond to the same species, $\lambda=1$, i.e. the highest values of $\lambda$ indicate the lowest taxonomic diversity for this assemblage (Buzas, 1979). When comparing the obtained values in both sections, in all upper Toarcian assemblages, some differences arise. In the section of Maria Pares, values indicate a decreasing trend in diversity towards the Toarcian-Aalenian boundary, while the section of Zambujal de Alcaria values reflect assemblages constituted by a high variability in number of specimens (between 16 and 708) and species ranging from values of 4 to 33. In recorded assemblages from Opalinum Biozone, the obtained values are more homogeneous in both sections, reflecting general environmental conditions appropriated for the development of relatively diverse communities. In the upper part of the Comptum Subzone and in the lower part of the Bradfordensis Subzone, diversity values decrease, probably reflecting unfavourable environmental conditions. Values of the Simpson index obtained in the Murtinheira section are very similar to those obtained in the sections studied in this work. They also indicate high diversity and no dominance of any species.

The Berger-Parker index allows the quantification of the dominance in an assemblage. In both sections, the obtained values are very similar and their trends are the same as those recognized in the previous index. The obtained values show that no clear dominance of one species can be recognized. The most abundant species is Lenticulina toarcense Payard displaying percentages between $14-45 \%$ in the section of Maria Pares and between 13-50\% in the section of Zambujal de Alcaria. However, in other coeval sections from the Lusitanian Basin like the sections of Murtinheira and São Gião, where no dominance is noted as well, the most abundant spe- cies are Lenticulina muensteri (Roemer) (Canales and Henriques, 2007, 2008) and Lenticulina helios (Terquem) (Henriques and Canales, 2013), respectively.

The obtained values of the Shannon-Wiener index are very similar in both sections and, as in the other measured indexes, the same trends can be observed. The lowest value of this index $\left(H^{\prime}=0\right)$ corresponds to an assemblage constituted by a single taxa, while the highest values indicate a diverse assemblage. According to Beerbower and Jordan (1969) the diversity is low when $H^{\prime}<0.6$, moderate when $0.6<H^{\prime}<$ 1 , and high when $H^{\prime}>1$. Following these authors, the values of this index obtained in the studied sections are always $>1$ and, as a consequence, diversity is high. Murray (1991) relates values of $H^{\prime}$ ' with paleoenvironmental conditions. Taking into account sedimentological interpretations of the studied sections, obtained values of this index and their relation with paleoenvironmental conditions established by this last author, the analyzed assemblages must have been developed in a marine platform with normal salinity.

Values of the Pielou's equitability obtained in the two studied sections are relatively high, quite constant and without significant variations in the whole studied stratigraphic interval. When all the species have the same number of specimens, then $J=1$, and this means that there is no dominance of any species. In addition, low values of equitability indicate conditions of high environmental stress (Haynes, 1981). As a consequence, in the assemblages from the sections of the Maria Pares and the Zambujal de Alcaria, no dominance of any species is detected and stressful environmental conditions do not seem to have occurred at any time.

High values of the Pielou's equitability were obtained in the section of Murtinheira indicating that also in the deeper part of the platform no dominance of any species was detected and no stressful conditions took place (Canales and Henriques, 2007, 2008).

The analysis of the obtained values from all indexes of diversity enables the differentiation of three intervals in the Maria Pares and the Zambujal de Alcaria sections (Figs. 7 and 8). Each of these intervals reflects different environmental features, which conditioned the development of the foraminiferal assemblages. The first interval spans from the Mactra Subzone until the lower part of the Opalinum Subzone. In the section of Maria Pares the values of the diversity indexes show a decrease trend in diversity towards the upper part of the interval that can reflect relatively inappropriate environmental conditions, the assemblages being less abundant and diverse towards the top of this interval. In the section of Zambujal de Alcaria, values obtained in this interval are irregular, which can indicate unstable environmental conditions giving rise to abundant and diverse assemblages alternating with more impoverished assemblages. From the upper part of the Opalinum Subzone, until the upper part of the Comptum Subzone, a second interval can be recognized. This episode is characterized by the homogeneity and high 
values obtained in all the indexes in both sections. This can reveal favourable and stable environmental conditions along the lower Aalenian, which enabled the development of abundant and diverse assemblages. The third recognized interval spans from the upper part of the Comptum Subzone, until the lower Bradfordensis Subzone. Here the values of the measured indexes tend to be low again, and may reflect unfavourable environmental conditions that hindered the development of abundant and diverse foraminiferal assemblages, probably related to a shallowing trend, as an upwards increase of limestone can be observed in this stratigraphic interval.

Differences in paleoenvironmental conditions recognized in the first interval of the two studied sections may be due to their different location within the platform, more proximal in the Zambujal de Alcaria area. From the Toarcian-Aalenian transition upwards, environmental conditions seem to have been more homogeneous in both sections, and probably in the whole basin, as data obtained from section of Murtinheira match the recorded data in the studied sections here (Canales and Henriques, 2007, 2008).

\section{Conclusions}

A total of 18,811 relatively well preserved specimens were obtained, corresponding to the 5 suborders, 13 families, 26 genera and 66 species. From a taxonomical point of view all of them are characteristic of carbonate platforms of the Boreal Realm, being comparable to other coeval sections of the Iberian Peninsula. All the assemblages are dominated by representatives of the suborder Lagenina, but regarding the second most abundant suborder, some differences have been noted, allowing the recognition of a gradient along the Lusitanian Basin, as follows: representatives of the suborder Spirillinina show the highest relative abundance in the distal part of the platform (section of Murtinheira), representatives of the suborder Miliolina show their maximum relative abundance in the transitional part of the platform (in the sections of Maria Pares and São Gião), and representatives of the suborder Textulariina displays their maximum relative abundance in the proximal part of the shelf (Zambujal de Alcaria area). The presence of all these suborders indicates normal and well-oxygenated marine conditions.

The genus Lenticulina, the most characteristic during the Middle and Late Jurassic, is the most abundant in all the assemblages of both sections, being Nodosaria in the Zambujal de Alcaria section, and Vinelloidea in the Maria Pares section the second ones in number of specimens obtained. Taxonomic composition at specific level is quite similar in both sections, being Lenticulina toarcense Payard the most abundant species.

The relative abundance values, as well as the obtained data from the diversity indexes applied, indicate that assemblages are relatively abundant and diverse, and no dominance of any species has been noted. Such results reflect general appropri- ate paleoenvironmental conditions for the development of the foraminiferal assemblages. However, detailed analysis of the data allows the identification in both sections of three different episodes, in terms of stability or instability, where such conditions appear to have failed.

The first episode (from the Mactra Subzone, until the lower part of the Opalinum Subzone) is represented by changing index values, especially in the Zambujal de Alcaria section that can reflect unstable environmental conditions. The second interval (from the lower part of the Opalinum Subzone until the upper part of the Comptum Subzone) is characterized by high and homogeneous values in all the indexes in both sections, reflecting favourable and stable environmental conditions which have allowed the development of abundant and diverse assemblages. The third episode (from the upper part of the Comptum Subzone until the lower Bradfordensis Subzone) shows again lower index values that may reflect unfavourable environmental conditions that hindered the development of the foraminiferal assemblages, probably related to changes in sedimentation. These data are consistent with previous results obtained in the section of Murtinheira, corresponding to the distal part of the platform, and with the section of São Gião, corresponding to the proximal part of the platform, both located in the Northern Lusitanian Basin. In this way the results of the present study clearly contribute to increase the knowledge of the paleoecological conditions prevailing within the Lusitanian Basin during the Early-Middle Jurassic boundary.

\section{Acknowledgements}

This study has been supported by the Projects CGL201123947 and CGL2011-25894 (Ministerio de Ciencia e Innovación, Spain) and by the Research Group UCM 910431 (Complutense University, Madrid, Spain). Laboratory works were supported by the Consortium Petrobras-Galp-Partex of Portugal. The authors are grateful to Dr. Jarosław Tyszka, to Dr. Guillermo Meléndez and to one anonymous reviewer for the critical review of the manuscript, to the Centro Nacional de Microscopía Electrónica (Complutense University of Madrid, Spain) for the SEM photographs, to Hélio Guterres for the preliminary work of a part of the studied material and to Jhonny Miranda for the English revision.

\section{References}

Alegret, L. (2004): Paleoecología y Reconstrucción Paleoambiental con Microfósiles. In: E. Molina (ed.), Micropaleontología. Prensas Universitarias de Zaragoza, Chapter 25. Zaragoza, pp. 523-552.

Azerêdo, A.C. (1993): Jurássico Médio do Maciço Calcário Estremenho (Bacia Lusitânica): análise de fácies, micropaleontologia, paleogeografia. Unpublished Ph.D. Thesis, Universidade de Lisboa, Portugal, $366 \mathrm{p}$.

Azerêdo, A.C. (1995): Foraminíferos bentónicos do Dogger da Bacia Lusitânica: valor estratigráfico e controlo ambiental. Memórias $\mathrm{Mu}$ seu e Laboratório Mineralógico e Geológico da Faculdade Ciências 
da Universidade do Porto 4, 29-32.

Azerêdo, A.C. (1999): Études micropaléontologiques dans les séries carbonatées du Jurassique moyen du Bassin Lusitanien (Portugal). Comunicações do Instituto Geológico e Mineiro, Lisboa 86, 59-84.

Azerêdo, A.C. (2007): Formalização da litostratigrafia do Jurássico Inferior e Médio do Maciço Calcário Estremenho, Bacia Lusitânica. Comunicações Geológicas, Instituto Nacional de Engenharia, Tecnologia e Inovação, Lisboa 94, 29-51.

Azerêdo, A.C., Duarte, L.V., Henriques, M.H., Manuppella, G. (2003): Da dinâmica continental no Triásico aos mares no Jurássico Inferior e Médio. Cadernos de Geologia de Portugal, Instituto Geológico e Mineiro, Lisboa, 43 p.

Barbieri, F. (1964): Micropaleontologia del Lias e Dogger del pozzo Ragusa 1 (Sicilia). Rivista Italiana di Paleontologia e Stratigrafia 70, 709-830.

Barbosa, B.P., Soares, A.F., Rocha, R.B., Manupella, G., Henriques, M.H.P. (2008): Notícia explicativa da folha 19A - Cantanhede. Carta Geológica de Portugal na escala de 1:50 000. Departamento de Geologia, Instituto Nacional de Engenharia, Tecnologia e Inovação, Lisboa.

Bartenstein, H., Brand, E. (1937): Mikro-paläontologische Untersuchungen zur Stratigraphie des nordwest-deutschen Lias und Doggers. Abhandlungen der Senckenbergischen Naturforschenden Gesellschaft 439, 1-224.

Beerbower, J.R., Jordan, D. (1969): Application of information theory to paleontologic problems: Taxonomic diversity. Journal of Paleontology 43, 1184-1198.

Bernhard, J.M. (1986): Characteristic assemblages and morphologies from anoxic, organic rich deposits: Jurassic through Holocene. Journal of Foraminiferal Research, 16, 207-215. doi:10.2113/gsjfr.16.3.207

Boutakiout, M. (1990): Les foraminifères du Jurassique des Rides sudrifaines et des régions voisines (Maroc). Documents des Laboratoires de Géologie de Lyon 112, 1-247.

Buzas, M.A. (1979): The measurement of species diversity. In: J.H. Lipps, W.H. Berger, M.A. Buzas, R.G. Douglas, C.A. Ross (eds.), Foraminiferal ecology and paleoecology. Society of Economic Paleontologists and Mineralogists, Short Course 6, pp. 3-10.

Canales, M.L. (2001): Los foraminíferos del Aaleniense (Jurásico Medio) en la Cuenca Vasco-Cantábrica (N de España). Revista Española de Micropaleontología 33, 253-438.

Canales, M.L., García-Baquero, G., Henriques, M.H., Figueiredo, V. (2014): Palaeoecological distribution pattern of Early-Middle Jurassic benthic foraminifera in the Lusitanian Basin (Portugal) based on multivariate analysis. Palaeogeography, Palaeoclimatology, Palaeoecology 410, 14-26. doi: 10.1016/j.palaeo.2014.05.007.

Canales, M.L., Henriques, M.H. (2007): Análisis cuantitativo de los foraminíferos del Aaleniense (Jurásico Medio) de la sección de Murtinheira (Cabo Mondego, W de Portugal). Consideraciones paleoecológicas. In: I.S. Carvalho, R.C.T. Cassab, C. Schwanke, M.A. Carvalho, A.C.S. Fernandes, M.A.C. Rodrigues, M.S.S. Carvalho, M. Arai, M.E.Q. Oliveira (eds.), Paleontologia: Cenários de Vida. Editora Interciência, Brasil, 2 vol., pp. 383-393.

Canales, M.L., Henriques, M.H. (2008): Foraminifera from the Aalenian and the Bajocian GSSP (Middle Jurassic) of Murtinheira section (Cabo Mondego, West Portugal): Biostratigraphy and paleoenvironmental implications. Marine Micropaleontology 67, 155-179. doi:10.2113/gsjfr.16.3.207

Canales, M.L., Henriques, M.H. (2013): Foraminiferal assemblages from the Bajocian Global Stratotype Section and Point (GSSP) at the Cape Mondego (Portugal). Journal of Foraminiferal Research 43, 182-206. doi:10.2113/gsjfr.43.2.182

Canales, M.L., Henriques, M.H., Figueiredo, V.L., Guterres, H. (2010):
Foraminifera from the Lower-Middle Jurassic of the Lusitanian Basin (Portugal) - biostratigraphic and palaeoecological significance: In: R. Pena dos Reis and N. Pimentel (eds.), Rediscovering the Atlantic: new ideas for an old sea. II Central \& North Atlantic Conjugate Margins Conference, Lisbon, 2010, pp. 42-46.

Canales, M.L., Herrero, C. (2000): Asociaciones de foraminíferos del Toarciense superior y Aaleniense en la sección de Moyuela (Zaragoza, España). Revista Española de Micropaleontología 32, 301-317.

Carapito, M.C., Henriques, M.H. (1999): Foraminiferal biostratigraphy and paleoecology of the Aalenian - Bajocian boundary at the Cabo Mondego area (Portugal). Abstracts European Palaeontological Association, Lisboa, pp. 35-38.

Carta Geológica de Portugal, à escala 1:1 000 000, Edição 2010. Laboratório Nacional de Energia e Geologia, Laboratório de Geologia e Minas (LNEG-LGM), Lisboa.

Coleman, B. (1981): The Bajocian to Callovian. In: D.G. Jenkins, J.W. Murray (eds.), Stratigraphical Atlas of Fossil Foraminifera, British Micropaleontological Society Series, Ellis Horwood Limited, Chichester, pp. 105-124.

Copestake, P., Johnson, B. (1981): The Hettangian to Toarcian (Lower Jurassic). In: D.G. Jenkins and J.W. Murray (eds.), Stratigraphic Atlas of Fossil Foraminifera, Ellis Horwood Ltd, Chichester, UK, pp. 81-105.

Cresta, S., Goy, A., Ureta, S., Arias, C., Barrón, E., Bernad, J., Canales, M.L., García-Joral, F., García-Romero, E., Gialanella, P.R., Gómez, J.J., González, J.A., Herrero, C., Martínez, G., Osete, M.L., Perilli, N., Villalaín, J.J. (2001): The Global Boundary Stratotype Section and Point (GSSP) of the Toarcian-Aalenian Boundary (Lower-Middle Jurassic). Episodes 24, 166-175.

Duarte, L.V. (2007): Lithostratigraphy, sequence stratigraphy and depositional setting of the Pliensbachian and Toarcian series in the Lusitanian Basin, Portugal. Ciências da Terra, Universidade Nova, Lisboa $16,17-23$.

Ellis, B.F., Messina, A. (1940-1990): Catalogue of Foraminifera. Museum of Natural History, New York.

Exton, J. (1979): Pliensbachian and Toarcian microfauna of Zambujal, Portugal: Systematic Paleontology. Carleton University, Geological Paper 79, 1-103.

Exton, J., Gradstein, F.M. (1984): Early Jurassic stratigraphy and micropaleontology of the Grand Banks and Portugal. In: G.E.G. Westermann (ed.), Jurassic-Cretaceous Biochronology and Paleogeography of North America, Geological Association of Canada, Special Paper 27, pp. 13-30.

Figueiredo, V.L. (2009): Foraminiferos da passagem Jurássico Inferior-Médio do Sector Central da Bacia Lusitânica: o perfil de Zambujal de Alcaria. Unpublished M.Sc. thesis, Universidade de Coimbra, Portugal, $88 \mathrm{p}$.

Figueiredo, V., Canales, M.L., Henriques, M.H. (2010a): Foraminíferos da passagem Jurássico Inferior-Médio da Bacia Lusitânica: os perfis da Murtinheira (Sector Setentrional) e de Zambujal de Alcaria (Sector Central). E-Terra 17, 1-4.

Figueiredo, V.L., Henriques, M.H., Canales, M.L. (2010b): Foraminíferos bentonicos da Passagem Jurássico Inferior - Médio do Sector Central da Bacia Lusitânica: o Perfil de Zambujal de Alcaria. Boletim de Geociências da Petrobras 19, 207-234.

Figueiredo, V., Guterres, H. (2012): Análise Quantitativa das Associações de Foraminíferos da Passagem Jurássico Inferior - Médio do Perfil de Maria Pares (Setor Norte da Bacia Lusitânica, Portugal) - Implicações Paleoecológicas. In: F.C. Lopes, A.I. Andrade, M.H. Henriques, M. Ferreira-Quinta, M.T. Barata, R. Pena dos Reis (eds.), Para Conhecer a Terra: Memórias e Notícias de Geociências no Espaço Lusófono, Imprensa da Universidade de Coimbra 1, p. 151-159. Ghandour, I.M., Maejima, W. (2007): Benthic foraminiferal biofacies 
distribution in the Middle Jurassic Safa Formation, Gebel Al-Maghara, Northern Sinai, Egypt: Paleoenvironmental implications. Neues Jahrbuch für Geologie und Paläontologie, Abhandlungen 245, 273-294. http://dx.doi.org/10.1127/0077-7749/2007/0245-0273

Grigelis, A., Norling, E. (1999): Jurassic geology and foraminiferal faunas in the NW part of the East European Platform. Research Papers, Sveriges Geologiska Undersökning, Series Ca 89, 1-99.

Guterres, H.C. (2010): Foraminiferos do limite Jurássico Inferior-Médio do Sector Norte da Bacia Lusitânica: o perfil de Maria Pares (Rabaçal). Unpublished M.Sc. thesis,Universidade de Coimbra, Portugal, $76 \mathrm{p}$.

Hammer, O., Harper, D.A.T. (2006): Paleontological Data Analysis. Blackwell Publishing, Oxford, $351 \mathrm{p}$.

Hammer, O., Harper, D.A.T., Ryan, P.D. (2001): PAST: paleontological statistics software package for education and data analysis. Palaeontologia Electronica 4, 9 p.

Haq, B.U., Hardenbol, J., Vail, P.R. (1988): Mesozoic and Cenozoic chronostratigraphy and cycles of sea-level change. In: C.K. Wilgus, B.S. Hastings, C.A. Ross, H. Posamentier, J. van Wagoner, C.G.S.C. Kendall (eds.), Sea-level Changes: Integrated Approach, SEMP Special Publication 42, pp. 71-108.

Haynes, J.R. (1981): Foraminifera. Macmillan Publishers Ltd., London, $433 \mathrm{p}$.

Henriques, M.H. (1992): Biostratigrafia e Paleontologia (Ammonoidea) do Aaleniano em Portugal (Sector Setentrional da Bacia Lusitaniana). Unpublished Ph.D. thesis, Universidade de Coimbra, Portugal, $301 \mathrm{p}$.

Henriques, M.H. (1995): Les faunes d'ammonites de l'Aalénien portugais: composition et implications paléobiogéographiques. Geobios 28 (suppl. 1), 229-235.

Henriques, M.H. (1998): Caracterização biostratigráfica do Aaleniano de Maria Pares (Rabaçal, Portugal): In: Livro Guia das Excursões do V Congresso Nacional de Geologia, Sociedade Geológica de Portugal, Lisboa, 1, p. 53-57.

Henriques, M.H.P. (2000): Aalenian of the Zambujal de Alcaria section (Central Lusitanian Basin; Portugal). Advances in Jurassic Research 2000. GeoResearch Forum, Transtec Pubications 6, pp. 85-94.

Henriques, M.H., Canales, M.L. (2013): Ammonite-benthic foraminifera turnovers across the Lower-Middle Jurassic transition in the Lusitanian Basin (Portugal). Geobios 46 (5), 395-408. doi: 10.1016/j. geobios.2013.06.002

Henriques, M.H., Soares, A.F., Carapito, M.C. (1995): O limite Aaleniano-Bajociano. O perfil da Serra da Boa Viagem (Portugal). Memórias, Museu e Laboratório Mineralógico e Geológico da Faculdade Ciências Universidade do Porto 4, 97-100.

Herrero, C., Canales, M.L. (1997): Diversidad en los foraminíferos del tránsito Toarciense/Aaleniense en la sección de Fuentelsaz (Cordillera Ibérica). Revista Española de Paleontología 12, 233-242.

Herrero, C., Canales, M.L. (2002): Taphonomic processes in selected Lower and Middle Jurassic foraminifera from the Iberian Range and Basque-Cantabrian Basin (Spain). Journal of Foraminiferal Research 32, 22-42. doi: 10.2113/0320022.

Johnson, B. (1976): Ecological ranges of selected Toarcian and Domerian (Jurassic) foraminiferal species from Wales. In: G.H.T. Schafer, R.P. Bernard (eds.), 1st International Symposium on Benthonic Foraminifera of Continental Margins. Part B: Paleoecology and Biostratigraphy, Halifax, 1975. Maritime Sediments, Special Publication 1, p. 545-556.

Loeblich, A.R., Tappan, H. (1987): Foraminifera genera and their classification. Van Nostrand Reinhold Company, New York, 970 p.

Magno, C. (2010): Foraminiferos do passagem Jurássico inferior-médio do sector Norte da Bacia Lusitânica: o perfil de S. Gião. Unpublished M.Sc. thesis, Universidade de Coimbra, Portugal, 86 p.
Magno, C., Henriques, M.H., Canales, M.L. (2008): Foraminíferos do Aaleniano (Jurássico Médio) da Ibéria: Bacias Lusitânica (Portugal), Basco-Cantábrica (Espanha) e Cordilheira Ibérica (Espanha): In: Conferência Internacional: As Geociências no Desenvolvimento das Comunidades Lusófonas. Memórias e Notícias da Universidade de Coimbra, (Nova Série), p. 115-122.

Magurran, A.E. (1988): Ecological diversity and its measurement. Chapman and Hall, London, 179 p.

Morris, P.H., Coleman, B.E. (1989): The Aalenian to Callovian (Middle Jurassic). In: D.G. Jenkins and J.W. Murray (eds.), Stratigraphical Atlas of Fossil Foraminifera, second edition. Ellis Horwood Limited, Chichester, UK, pp. 189-236.

Murray, J.W. (1989): An outline of faunal changes through the Phanerozoic. In: D.G. Jenkins and J.W. Murray (eds.), Stratigraphical Atlas of Fossil Foraminifera, second edition. Ellis Horwood Limited, Chichester, UK, pp. 570-573.

Murray, J.W. (1991): Ecology and Paleoecology of Benthic Foraminifera. John Wiley and Sons Inc., New York, 397 p.

Nagy, J. (1992): Environmental significance of foraminiferal morphogroups in Jurassic North Sea deltas. Palaeogeography, Palaeoclimatology, Palaeoecology 95, 111-134. http://dx.doi.org/10.1016/00310182(92)90168-5

Nagy, J. (2005): Delta-influenced foraminiferal facies and sequence stratigraphy of Paleocene deposits in Spitsberger. Palaeogeography, Palaeoclimatology, Palaeoecology 222, 161-179. http://dx.doi. org/10.1016/j.palaeo.2005.03.014

Nagy, J., Johansen, H.O. (1991): Delta-influenced foraminiferal assemblages from the Jurassic (Toarcian-Bajocian) of the northern North Sea. Micropaleontology 37, 1-40. http://www.jstor.org/stable/148574

Nagy, J., Pilskog, B., Wilhelmsen, M. (1990): Facies controlled distribution of foraminifera in the Jurassic North Sea Basin. In: C. Hemleben, M.A. Kaminski, W. Kuhnt and D.B. Scott (eds.), Paleoecology, Biostratigraphy and Taxonomy of Agglutinated Foraminifera, Kluwer Academic Publishing, Amsterdam, pp. 621-657.

Reolid, M., Chakiri, S., Bejjaji, Z. (2013): Adaptative strategies of the Toarcian benthic foraminiferal assemblages from the Middle Atlas (Morocco): palaeoecological implications. Journal of African Earth Science, 84, 1-12. doi: 10.1016/j.jafrearsci.2013.03.008

Reolid, M., Rodríguez-Tovar, F.J., Nagy, J., Olóriz, F. (2008): Benthic foraminiferal morphogroups of mid to outer shelf environments of the Late Jurassic (Prebetic Zone, Southern Spain): characterization of biofacies and environmental significance. Palaeogeography, Palaeoclimatology, Palaeoecology 261, 280-299. doi: 10.1016/j.palaeo.2008.01.021

Reolid, M., Sebane, A., Rodríguez-Tovar, F.J., Marok, A. (2012): Foraminiferal morphogroups as a tool to approach the Toarcian Anoxic Event in the Western Saharan Atlas (Algeria). Palaeogeography, Palaeoclimatology, Palaeoecology 323-325, 87-99. doi: 10.1016/j. palaeo.2012.01.034

Ribeiro, A., Antunes, M.T., Ferreira, M.P., Rocha, R.B., Soares, A.F., Zbyszewski, G., Moitinho de Almeida, F., Carvalho, D., Monteiro, J.H. (1979): Introduction à la géologie générale du Portugal. Serviços Geológicos de Portugal, Lisboa, 114 p.

Ruget, C. (1985): Les Foraminifères (Nodosariidés) du Lias de L'Europe occidentale. Documents des Laboratoires de Géologie de Lyon 94, pp. $1-272$.

Scheibnerová, V. (1968): On the discovery of Microfauna in the Opalinus Beds (Klippen Belt, West Carpathians). Mitteilungen der Bayerischen Staatssammlung für Paläontologie und historische Geologie 8, 51-65.

Stam, B. (1985): Quantitative analysis of Middle and Late Jurassic foraminifera from Portugal and its implications for the Grand Banks of Newfoundland. Utrecht Micropaleontological Bullentins 34, 1-168. 
Tyszka, J. (1994a): Paleoenvironmental implications from ichnological and microfaunal analyses of Bajocian Spotty Carbonates, Pieniny Klippen Belt, Polish Carpathians. Palaios 9, 175-187. doi: $10.2307 / 3515104$

Tyszka, J. (1994b): Response of Middle Jurassic benthic foraminiferal morphogroups todysoxic/anoxic conditions in the Pieniny Klippen Basin, Polish Carpathians. Palaeogeography, Palaeoclimatology, Palaeoecology 110, 55-81. doi: 10.1016/0031-0182(94)90110-4

Tyszka, J. (1999): Foraminiferal Biozonation of the Early and Middle Jurassic in the Pieniny Klippen Belt (Carpathians). Bulletin of the Polish Academy of Sciences, Earth Sciences 47, 27-46.

Tyszka, J. (2001): Microfossil assemblages as bathymetric indicators of the Toarcian/Aalenian «Fleckenmergel»-facies in the Carpathian Pieniny Klippen Belt. Geologica Carpathica 52, 47-158.

Wernli, R. (1971): Les foraminifères du Dogger du Jura méridional (France): Archives des Sciences 24, 305-364.

Wilson, R.C.L. (1988): Mesozoic development of the Lusitanian Basin, Portugal. Revista Sociedad Geológica España 1, 393-407.

Wilson, R.C.L., Hiscott, R.N., Willis, M.G., Gradstein, F.M. (1989): The Lusitanian Basin of West Central Portugal: Mesozoic and Tertiary Tectonic, Stratigraphic, and Subsidence History. In: A.J., Tankard, H. Balkwill (eds.), Extensional tectonics and stratigraphy of the North Atlantic margins, American Association of Petroleum Geologists Memoir 46, pp. 341-361. 